\section{Evaluation of in-service training program named Technology Usage Course in Education $^{1}$}

\section{Eğitimde Teknoloji Kullanımı Kursu hizmetiçi eğitim programının değerlendirilmesi}

\author{
Eyüp İzci ${ }^{2}$ \\ Mehmet Eroğlu ${ }^{3}$
}

\section{Özet}

$\mathrm{Bu}$ araştırmanın amac1 FATIH projesi kapsamında öğretmenlere verilen "Eğitimde Teknoloji Kullanımı Kursu" hizmetiçi programını öğretmen ve formatör öğretmen görüşlerine göre değerlendirmektir. Çalş̧mada karma araştırma desenlerinden "yakınsayan paralel karma desen kullanılmışıtır. Araştırmanın nicel kısmına ilişkin veriler 92 öğretmenden anket yoluyla, nitel kısmına ilişsin veriler ise araştırmaya gönüllü kattlan 49 öğretmen ve 5 formatör ögrtetmenden görüşme yoluyla elde edilmiştir. Araşıtrmadan elde edilen nicel verilerin analizinde betimsel istatistik, nitel verilerin analizinde içerik analizi kullanılmıştrr. Araştırma bulgularına göre Eğitimde Teknoloji Kullanımı Kursu hizmetiçi eğitim programının kısmen başarılı olduğu ancak aksaklikların ve sorunlarında olduğu hem öğretmenler hem de formatör öğretmenler tarafindan vurgulanmıştrr. Öğretmenler programın, eğitimde teknoloji entegrasyonu bağlamında katk1 sağladığı ancak zaman, alt yap1 ve pratik yapma, eğitmen niteliği gibi konularda sorunların olduğunu belirtmisslerdir. Formatör öğretmenlerde programın eğitim teknolojileri kullanma özelliği açısından öğretmenlere katkı sağladığını ancak katulımc1 özellikleri, programın niteliği, alt yapı

\footnotetext{
${ }^{1}$ Bu çalışma, 4-6 Eylül 2014 tarihinde koceli’nde gerçekleștirilen 23. Ulusal Eğitim Bilimleri Kongresinde sözlü bildiri olarak sunulmuş̧ur

${ }^{2}$ Assist. Prof. Dr., İnonu University, Education Faculty, Educational Sciences, eyup.izci@inonu.edu.tr

${ }^{3}$ Research Asistant, Firat University, Education Faculty, Educational Sciences, mehmeteroglu@,firat.edu.tr
} 
İzci, E. \& Eroğlu, M. (2016). Eğitimde Teknoloji Kullanımı Kursu hizmetiçi eğitim programının değerlendirilmesi. International Journal of Human Sciences, 13(1), 1666-1688. doi:10.14687/ijhs.v13i1.3584

Technologies but they reported that there are problems in the points of participant characteristics, quality of program, infrastructure and time. The result of study shows that quality of this in-service training program is not on desired level and this result has been shown to be supported by quantitative and qualitative findings in this study.

Keywords: FATİH Project, In-Service Training; Professional Development; Technology Integration in Education; Mixed Method Research.

(Extended English abstract is at the end of this document) ve zaman konularında sorunların olduğunu ifade etmişlerdir. Araşturmanın sonucuna göre bu hizmetiçi eğitim programının istenilen düzeyde olmadığ1 ve bu durumun nicel-nitel bulgularla desteklendiği görülmüştür.

Anahtar Kelimeler: FATİH Projesi; Hizmetiçi Eğitim; Mesleki Gelişim; Eğitimde Teknoloji Entegrasyonu; Karma Araştırma Yöntemi.

\section{Giriş}

Teknolojinin hızla geliştiği günümüzde eğitimin bu gelişmelerden etkilenmemesi olanaksız görünmektedir. Nitekim teknolojik araçlar ile öğrenme sürecinde yeni yöntem ve tekniklerin kullanılması mümkün hale gelmiş ve bu sayede öğrenme ortamlarının düzenlenmesinde birçok yenilik ve düzenlemeler ortaya çıkmıştır (Usta ve Korkmaz, 2010). Eğitim sistemleri de bu teknolojik gelişmeler doğrultusunda yeni programlar, yeni materyaller hazırlama gereği duymaktadırlar (Adıgüzel, 2010; Yeşilyurt, 2007). Ülkemiz eğitim sistemi de bu gelişmelerden etkilenmektedir. 2005 yllında ilköğretim programlarının yenilenmesiyle başlayan süreç ortaöğretim programlarının yenilenmesiyle devam etmiştir. Yapılandırmacilığ1 temel alan bu programların temelinde yer alan öğrenci merkezlilik, aktif katıllım, öğretmen rehberliği, problem çözme ve teknoloji okuryazarlığ gibi temel yaklaşımlar da programdaki teknoloji entegrasyonunu zaruri kılmaktadır. Bu kapsamda eğitimde teknoloji entegrasyonuna yönelik çalışmalar ağırlık kazanmıştır. Zaten Türkiye'de de uzun yıllardır, okullarda bilişim teknolojilerinin entegrasyonu devlet politikası olarak sürdürülmekte, değişim ve gelişim süreci yeni projelerle devam etmektedir. Bu bağlamda 2010 yllinda tanıtılan FATİH (Fırsatları Arttırma ve Teknolojiyi İyileştirme Hareketi) projesi de bunlardan biridir (Demirer, Saban, Küçük \& Şahin, 2011).

Türkiye'nin önemli yatırımlanından biri olan ve başlangicta 3 yıl içerisinde tamamlanması planlanan FATIHH projesinin bütçesi 3 milyar TL olarak hesaplanmıştır (TOBB, 2010). Ancak pilot uygulama ve değerlendirme sonuçlarına göre projenin maliyeti bu rakamın üzerinde olacağ1 açıklanmışur (Eryılmaz ve Salman 2104). Türk eğitim-öğretim sisteminde teknoloji odaklı bir değişim süreci olarak tanımlanan (Akınc1, Kurtoğlu, Seferoğlu, 2012) FATİH Projesi, eğitim ve öğretimde firsat eşitliğini sağlamak ve okullarımızdaki teknolojiyi iyileştirmek amaciyla BT araçlarının öğrenme-öğretme sürecinde daha fazla duyu organına hitap edilecek şekilde, derslerde etkin kullanımı için; okulöncesi, ilköğretim ile ortaöğretim düzeyindeki tüm okulların 570.000 dersliğine LCD Panel Etkileşimli Tahta ve internet ağ altyapısının sağlanması amaçlanmaktadır (MEB, 2013a). Pilot uygulama kapsamında her öğretmene ve her öğrenciye tablet bilgisayar verilmesi planlanmıştır. Dersliklere kurulan BT donanımının öğrenme-öğretme sürecinde etkin kullanımını sağlamak amacıyla öğretmenlere hizmetiçi eğitimler verilmesi de planlanmıştır. Bu süreçte ilköğretim ve ortaöğretim programları BT destekli ögretime uyumlu hale getirilerek eğitsel eiçerikler oluşturulmasına yönelik çalışmalar başlatılmıştır. Bu kapsamda Eğitimde FATİH projesi beş ana bileşenden oluşmaktadır. Bunlar: 1. Donanım ve Yazılım Altyapısının Sağlanması, 2. Eğitsel e-İçeriğin Sağlanması ve Yönetilmesi, 3. Öğretim Programlarında Etkin BT Kullanımı, 4. Öğretmenlerin Hizmetiçi Eğitimi, 5. Bilinçli, Güvenli, Yönetilebilir ve Ölçülebilir BT Kullanımının 
İzci, E. \& Eroğlu, M. (2016). Eğitimde Teknoloji Kullanımı Kursu hizmetiçi eğitim programının değerlendirilmesi. International Journal of Human Sciences, 13(1), 1666-1688. doi:10.14687/ijhs.v13i1.3584

sağlanmasıdır. Eğitimde FATİH Projesi Millî Eğitim Bakanlığı tarafindan yürütülmekte olup, Ulaştırma Bakanlı̆g tarafindan desteklenen bir projedir.pilot uygulamalar sonucunda 5 yılda tamamlanması öngörülmektedir. Birinci yıl ortaöğretim okulları, ikinci yıl ilköğretim ikinci kademe, üçüncü yıl ise ilköğretim birinci kademe ve okul öncesi kurumlarının BT donanım ve yazılım altyapısı, e-içerik ihtiyac1, öğretmen kılavuz kitaplarının güncellenmesi, öğretmenler için hizmetiçi eğitimler ve bilinçli, güvenli, yönetilebilir BT ve internet kullanımı ihtiyaçlanının tamamlanması hedeflenmektedir (MEB, 2013a). Projenin uygulama süreci halen devam etmektedir. Bu kapsamda okullarda donanım ve yazılım alt yapısının sağlanması, öğrencilere ve öğretmenlere tabletlerin dağıtılması, e-içerik oluşturma, öğretmenlere hizmetiçi eğitimlerin verilmesi çalışmaları yürütülmektedir. Nisan 2013 itibarılla 120.000'den fazla öğretmen eğitim almıştır. (Eğitim Reformu Girişimi(ERG), 2013).

FATİH projesi eğitimde teknoloji kullanımına ilişkin altyapı, donanım sağlamasının yanında öğretmenlerin hizmetiçi eğitimini de kapsamaktadır. FATİH projesi kapsamında öğretmenlere yönelik hizmetiçi eğitimler verilmektedir. Bu hizmet içi eğitimler 8 saatlik FATİH projesi tanıtım seminerleri, 10 saatlik FATİH projesi bilişim teknolojilerinin ve internetin bilinçli, güvenli Kullanımı semineri, 25 saatlik FATİH projesi hazırlayıcı eğitim ve 30 saatlik Eğitimde Teknoloji Kullanımı Kursudur (MEB, 2012). "Eğitimde Teknoloji Kullanımı Kursu (ETKK)" hizmetiçi eğitimi FATİH projesi kapsamındaki araç gereçlerin kurulumu, etkileşimli tahtaların kullanımı, eğitsel yazılımların kullanılması ve hazırlanması gibi temel hedefleri gerçekleştirmeye dönük diğerlerine göre daha kapsamlı bir hizmetiçi eğitim programıdır. Bu nedenle FATİH projesindeki hizmetiçi eğitimlerin omurgasını oluşturduğu düşünülmektedir. Bu kurs programını tamamlayan öğretmenden aşağıda belirtilen yeterlikler beklenmektedir (MEB, 2013b).

- Eğitimde Fatih Projesinin amacını, kapsamını ve beklentilerini bilir,

- İnterneti bilinçli ve güvenli kullanır,

- Proje kapsamında sağlanan bilgi teknolojileri ekipmanlarının kurulumunu, kullanımını yapar ve karşılaşılan temel problemleri çözer,

- Etkileşimli tahta ve yazılımını kullanır,

- Eğitimde teknoloji kullanımı kavramlarını bilir,

- Öğretim sürecinde materyalleri yerinde kullanır,

- Eğitim Bilişim Ağındaki materyalleri (EBA) ders sürecinde kullanır,

- İnternet üzerinde yayımlanan, ders etkinliklerinde kullanabileceği materyalleri arar, bulur ve telif haklarına uygun olarak seçer,

- Seçilen materyal üzerinde değişiklik yapar,

- İhtiyaç duyduğu konularda materyal tasarlar,

- Bulunan/değiştirilen/tasarlanan materyali etkili kullanmak üzere bir ders planı hazırlar,

- Plana uygun olarak etkileşimli tahta ile dersini sunar,

- Materyalin etkililiğini ve verimliliğini değerlendirir.

Bu yeterlikleri sağlamak amacıyla Milli Eğitim Bakanlığı tarafindan öğretmenlere yönelik 30 saatlik kurs planlanmıştır. Bu kursun içeriğinde ise internet kullanımı, etkileşimli tahta kullanımı, eğitsel oyun, simülasyon, akademik bloglar, e-öğrenme, e-içerik ve bunların kullanımı, materyal seçimi, materyal hazırlanması, değerlendirme yer almaktadır. Uygulama ağırlıklı bir öğretim sürecini içeren bu kursta öğretmenler hazırladıkları uygulamalara göre değerlendirilmektedir. Kurslar MEB tarafindan belirlenen formatör öğretmenler tarafindan mahalli olarak yürütülmektedir (MEB, 2013b).

Hizmetiçi eğitimler öğretmenlerin mesleki gelişimi ve dolayısıyla eğitimde niteliğin arttırılması için önemlidir. Türkiye'nin önemli yatırımlarından biri olan FATİH projesi bağlamında eğitimde teknoloji entegrasyonunun sağlanmasında öğretmenler önemli bir role sahiptir. Çünkü bu önemli projeyi ürüne dönüştürecek olanlar şüphesiz öğretmenlerlerdir. Bu bağlamda öğretmenlerin 
İzci, E. \& Eroğlu, M. (2016). Eğitimde Teknoloji Kullanımı Kursu hizmetiçi eğitim programının değerlendirilmesi. International Journal of Human Sciences, 13(1), 1666-1688. doi:10.14687/ijhs.v13i1.3584

öğretme-öğrenme sürecinde öğretim teknolojilerinin kullanımına ilişkin olumlu tutumları ve yeterlikleri (Kayaduman, Sırakaya, Seferoğlu, 2011) önemlidir. Çünkü birçok okulda yeterli öğretim teknolojileri olmasına rağmen öğretmenlerin teknoloji kullanımına ilişkin olumsuz tutumlarından dolayı bunları çok az kullandıkları ya da hiç kullanmadıkları bilinmektedir (Adıgüzel, 2010). Öğretmenlerin olumsuz tutumlarının altında ise teknoloji kullanımına ilişkin yetersizlikler ve ön yargıların etkili olabileceği düşünülmektedir. Bu nedenle öğretmenlerde olumlu tutumlar oluşturmak için teknoloji kullanımına ilişkin gerekli bilgi-becerilerin kazandırılması gerekmektedir. Bu bilgi ve becerilerin kazandırılması da ağıllıklı olarak hizmetiçi eğitimle sağlanmaktadır. Bu nedenle öğretmenlerin hizmetiçi eğitimi üzerinde önemle durulması gereken bir konudur. Başarllı olunmak isteniyorsa mesleki başarının ön koşulu olan hizmet-içi eğitimler konusunda gerçekçi yaklaşımlar izlenmeli (Akınc1, Kurtoğlu, Seferoğlu, 2012) hizmetiçi eğitimler değerlendirilmeli (Bümen, Ateş, Çakar Ural ve Acar, 2012) ve böylece hizmet-içi eğitimlerin niteliği artırılmalıdır.

FATİH projesine ilişkin literatürde birçok çalışma olmasına rağmen projeye ilişkin hizmetiçi eğitimlerle ilgili çalışmaların sayısı azdır. Yıldız, Sarıtepeci ve Seferoğlu (2013) tarafindan yapılan çalışmada FATİH projesi kapsamında eğitimde teknoloji kullanımının yaygınlaştırılmasında hizmetiçi eğitimlerin öğretmenlerin mesleki gelişimlerine katkılarının Uluslararası Eğitim Teknolojileri Birliği (International Society for Technology in Education)'in standartlanna göre değerlendirilmesi amaçlanmıştır. Çalışmada öğretmenlerin hizmet-içi eğitimlerinde ciddi eksikliklerin olduğunu belirtmeleri göze çarpmaktadır. Tatlı ve Kılıç (2013)' in, FATİH projesi kapsamında etkileşimli tahtaların kullanımına yönelik verilen hizmetiçi eğitimin öğretmen görüşleri doğrultusunda değerlendirmeyi amaçlayan çalışmalarında da öğretmenler etkileşimli tahta kullanımı ile ilgili aldıkları eğitimin etkileşimli tahtayı etkin bir şekilde kullanma konusunda yetersiz olduğu belirtmişlerdir. Bunun yanında zaten MEB'in öğretmenlere sunduğu hizmetiçi eğitim etkinliklerine bakıldığında bu konuda pek de başarılı olmadığı görülmektedir (Akınc1, Kurtoğlu, Seferoğlu, 2012). Bu bağlamda FATİH projesi kapsamında gerçekleştirilen hizmetiçi eğitimlerde de sıkıntıların olduğu anlaşılmaktadır.

Teknolojinin eğitim ve öğretime adaptasyonunda özellikle öğretmenlerin rolü çok önemlidir (Çakır ve Oktay, 2013). Bu adaptasyon sürecini etkileyen birçok faktör vardır. Bu faktörler arasından öğretmenlerin teknolojiye karşı geliştirdikleri tutum, teknolojiyi kullanma gayretleri ve kullanım becerileri tartşsmasız ögrencilerinin teknoloji kullanımını ve tutumunu da etkilemektedir (Ertmer, 2005). Bu nedenle meslek yaşamında öğretmelerin tutumlarının, bilgi-becerilerinin ve gayretlerinin artırlması beklenmektedir. Bu bağlamda öğretmenlerin sürekli öğrenme ihtiyaçları ve hizmetiçi eğitim önemlidir. Çünkü hizmetiçi eğitimle öğretmenler bu konudaki bilgi beceri ve gayretlerini artırarak olumlu tutum geliştirebilirler. Bu kapsamda öğretmenler uygulanacak olan hizmetiçi eğitiminde nitelikli ve öğretmenlerin ihtiyaçlarını karşılayan bir biçimde hazırlanması ve uygulanması gerekmektedir.

Özellikle ETKK, FATİH projesinde öne çıkan etkileşimli tahtanın kullanımına yönelik verilen en önemli hizmetiçi eğitim programıdır. Çünkü hazırlayıcı eğitim öğretmenlerin temel bilgisayar bilgileri, internet kullanımı ve bazı temel programların kullanımına yoğunlaşmakta ve ETTK için basamak oluşturmaktayken, bilişim teknolojilerinin bilinçli ve güvenli kullanımı semineri özellikle öğrencilerin, öğretmenlerin ve velilerin BT kullanımına ilişkin bilinçlendirmeyi amaçlamaktadır. Oysa ETTK FATİH projesi kapsamındaki araç gereçlerin kurulumu, etkileşimli tahta kullanımı, materyal tasarlama, seçme, ve değerlendirme gibi yeterliklere odaklanmaktadır (Ekici ve Yılmaz, 2013). Bu bağlamda gerek hedefleri gerekse kapsamı bakımından ETKK' nun FATİH projesi kapsamında verilen hizmetiçi programların omurgasını oluşturduğu düşünülmektedir. Dolayısıyla FATİH projesinin başarıya ulaşmasında önemli bir basamak olarak görülebilir. Ancak FATİH projesi kapsamındaki hizmetiçi eğitimlere ilişkin yapılan çalışmalarda, bu hizmetiçi eğitimlere ilişkin sorunların olduğu belirlenmiştir (Tatlı ve Kıllı̧ 2013; Yıldız, Sarıtepeci ve Seferoğlu, 2013; Özkan ve Deniz, 2014). Bu sorunların daha derinlemesine ve bütüncül bir şekilde ele alınabilmesi gerekmektedir. Bu da farklı paydaşların katılımılla ve çeşitli veri toplama araçlarıyla 
İzci, E. \& Eroğlu, M. (2016). Eğitimde Teknoloji Kullanımı Kursu hizmetiçi eğitim programının değerlendirilmesi. International Journal of Human Sciences, 13(1), 1666-1688. doi:10.14687/ijhs.v13i1.3584

yapılacak bir çalışmanın yapılmasıyla mümkün olabilmektedir. Bu çalışma çeşitli veri toplama araçları ve farklı paydaşların katılımına imkan tanıyacağından alanyazına katkıda bulunacağı düşünülmektedir. Bu perspektiften, ETKK hizmetiçi programının değerlendirilmesi FATIH projesinin amaçlarına ulaşmasını sağlamak bakımından da önemli dönütler sağlayacaktır.

\subsection{Araştırmanın Amacı}

$\mathrm{Bu}$ araştırmanın amacı FATİH projesi kapsamında öğretmenlere verilen ETKK hizmetiçi programını öğretmen ve formatör öğretmen görüşlerine göre değerlendirmektir. Bu kapsamda şu genel sorulara cevap aranacaktır:

1. Öğretmenler bu programda beklenen hedeflere ne düzeyde ulaşttlar?

2. Öğretmenlerin programa ilişkin görüşleri nelerdir?

- Öğretmenlerin programın katkılarına ilişkin görüşleri nelerdir?

- Öğretmenlerin programın aksaklıklarına ve sorunlarına ilişkin görüşleri nelerdir?

3. Formatör öğretmenlerin programa ilişkin görüşleri nelerdir?

- Formatör öğretmenlerin programın öğretmenlere katkılarına ilişkin görüşleri nelerdir?

- Formatör öğretmenlerin programın aksaklıklarına ve sorunlarına ilişkin görüşleri nelerdir?

\section{Yöntem}

\subsection{Araştırmanın Modeli}

Bu çalışmada karma araştırma desenlerinden yakınsayan parallel karma desen (Convergent parallel mixed research method) kullanılmıştır. Karma araştırma; tek bir çalışma ya da çalışmalar dizisindeki aynı temel olgulara ilisskin nitel ve nicel veriler toplamayı, onlanı analiz etmeyi ve yorumlamay1 içermektedir (Leech ve Onwuegbuzie, 2009). Yakınsayan paralel desende araştırmacının, nicel ve nitel aşamalanı araştırma sürecinin aynı aşamasında eş zamanlı olarak uygulaması şeklindedir. Bu desen yöntemlere eşit öncelik verir. Analiz sırasında bu aşamalar birbirinden ayrı tutulur ve daha sonra genel yorumlama yaparken sonuçları birleştirilir (Cresswell ve Clark, 2011). Morse (1991) bu desenin amacını araştırma problemini en iyi şekilde anlamak için "aynı konu üzerinde farklı fakat birbirini tamamlayıcı veri toplamak olarak ifade etmiştir (Akt. Cresswell ve Clark, 2014). Program değerlendirmede farklı ve zengin veri kaynaklarının kullanılması önemlidir. Bu çalışma, bir program değerlendirme çalışması olarak düşünüldüğünden farklı ve zengin veri kaynaklarını, veri toplama araçlarını kullanmaya firsat veren, tamamlayıcı veriler toplanarak mevcut durumun tam olarak anlaşılması sağlayan bu desen kullanılmıştır.

\section{2. Çalışma Grubu}

ETKK hizmetiçi eğitim programını öğretmen görüşlerine göre değerlendirmek amacıyla yapılan bu araştırmanın çalışma grubu, ölçüt örnekleme yöntemiyle, Malatya ili şehir merkezinde yer alan ortaöğretim okullarında görev yapan ve bu hizmetiçi eğitim programına katılan öğretmenlerden ve bu hizmetiçi eğitimi veren formatör öğretmenlerden oluşmaktadır. Araştırmanın nicel kısmında yeralan anketi yanıtlayan katılımcılara ilişkin bilgiler aşağıda tablo 1 'de verilmiştir. 
İzci, E. \& Eroğlu, M. (2016). Eğitimde Teknoloji Kullanımı Kursu hizmetiçi eğitim programının değerlendirilmesi. International Journal of Human Sciences, 13(1), 1666-1688. doi:10.14687/ijhs.v13i1.3584

Tablo 1. Calisma Grubuna İliskin Demografik Bilgiler

\begin{tabular}{|c|c|c|c|}
\hline \multicolumn{2}{|l|}{ Değişken } & f & $\%$ \\
\hline \multirow[b]{2}{*}{ Cinsiyet } & Kadın & 19 & 21 \\
\hline & Erkek & 73 & 79 \\
\hline \multirow[b]{2}{*}{ Eğitim Durumu } & Lisans & 16 & 17 \\
\hline & Yüksek Lisans & 76 & 83 \\
\hline \multirow{4}{*}{ Kidem } & $1-15$ & 38 & 42 \\
\hline & $16-20$ & 23 & 25 \\
\hline & $21-30$ & 24 & 26 \\
\hline & 30 ve üzeri & 7 & 7 \\
\hline \multirow{17}{*}{ Branş } & Matematik & 14 & 15 \\
\hline & Türk Dili ve Edebiyatı & 12 & 13 \\
\hline & Yabanc1 Dil & 12 & 13 \\
\hline & Meslek Dersleri & 10 & 11 \\
\hline & Tarih & 9 & 10 \\
\hline & Coğrafya & 7 & 8 \\
\hline & Fizik & 6 & 7 \\
\hline & Kimya & 5 & 5 \\
\hline & Felsefe & 3 & 3 \\
\hline & Rehberlik & 3 & 3 \\
\hline & Bilişim Teknolojileri & 2 & 2 \\
\hline & Biyoloji & 2 & 2 \\
\hline & Beden Eğitimi & 2 & 2 \\
\hline & Müzik & 2 & 2 \\
\hline & Din Kültürü ve Ahlak Bilgisi & 2 & 2 \\
\hline & Resim & 1 & 1 \\
\hline & Toplam & 92 & 100 \\
\hline
\end{tabular}

Araştırmanın nitel bölümüne ilişkin veriler ETKK 'nu Malatya ilinde yürüten 5 formatör öğretmenle, araştırmanın nicel kısmına katulmış ve nitel görüşme için gönüllü olan 49 öğretmenden elde edilmiştir. Katılımcılardan formatör öğretmenler "FÖ" şeklinde, öğretmenler ise "Ö” şeklinde belirtilmiştir. Araştırmanın nitel kısmına katılan öğretmenlere ilişkin bilgiler tablo 2'de verilmiştir.

Tablo 2. Arastırmanm Nitel Bölümünün Katılmmclarnna Ait Bilgiler

\begin{tabular}{|c|c|c|c|c|c|c|c|}
\hline $\begin{array}{l}\text { Kat1limc } \\
1\end{array}$ & $\begin{array}{l}\text { Cinsiye } \\
\mathrm{t}\end{array}$ & Kidem & Branş & Katılımc1 & $\begin{array}{l}\text { Cinsiye } \\
t\end{array}$ & Kidem & Branş \\
\hline FÖ1 & Erkek & $16-20 \mathrm{yll}$ & $\overline{\text { BT }}$ & Ö48 & Erkek & $1-15 \mathrm{yll}$ & Matematik \\
\hline FÖ2 & Erkek & $1-15 \mathrm{yll}$ & BT & Ö50 & Erkek & $16-20 \mathrm{yll}$ & Beden Eğitimi \\
\hline FÖ3 & Erkek & $1-15 \mathrm{yll}$ & BT & Ö52 & Kadin & $16-20 \mathrm{yll}$ & Biyoloji \\
\hline FÖ4 & Erkek & $1-15 \mathrm{yll}$ & BT & Ö53 & Erkek & $21-30 \mathrm{yll}$ & Tarih \\
\hline FÖ5 & Erkek & $1-15 \mathrm{yll}$ & BT & Ö54 & Erkek & $1-15 \mathrm{yll}$ & Tarih \\
\hline Ö1 & Erkek & $16-20 \mathrm{yll}$ & Tarih & Ö56 & Erkek & $16-20 \mathrm{yll}$ & Görsel sanatlar \\
\hline Ö7 & Erkek & $1-15 \mathrm{yll}$ & Coğrafya & Ö57 & Erkek & $16-20 \mathrm{yll}$ & Kimya \\
\hline Ö10 & Erkek & $1-15 \mathrm{yll}$ & Yabanc1 dil & Ö58 & Kadın & $1-15 \mathrm{yll}$ & Yabanc1 Dil \\
\hline Ö12 & Erkek & $1-15 \mathrm{yll}$ & Edebiyat & Ö60 & Erkek & $1-15 \mathrm{yll}$ & Sosyoloji \\
\hline Ö13 & Erkek & $21-30 \mathrm{yll}$ & Meslek Dersleri & Ö61 & Kadın & $1-15 \mathrm{yll}$ & Edebiyat \\
\hline Ö14 & Erkek & $21-30 \mathrm{yll}$ & Matematik & Ö62 & Erkek & $1-15 \mathrm{yll}$ & BT \\
\hline Ö15 & Kadın & $15-20 \mathrm{yll}$ & & Ö63 & Erkek & $1-15 \mathrm{yll}$ & Edebiyat \\
\hline Ö18 & Erkek & $1-15 \mathrm{yll}$ & Edebiyat & Ö64 & Erkek & $1-15 \mathrm{yll}$ & Tarih \\
\hline Ö19 & Erkek & $16-20 \mathrm{yil}$ & Yabanc1 dil & Ö66 & Erkek & 30 yıl üstü & Tarih \\
\hline Ö25 & Erkek & $21-30 \mathrm{yll}$ & Kimya & Ö68 & Erkek & $1-15 \mathrm{yll}$ & Görsel sanatlar \\
\hline Ö27 & Erkek & $1-15 \mathrm{yll}$ & Edebiyat & Ö69 & Erkek & $21-30 \mathrm{yll}$ & Din kültürü \\
\hline
\end{tabular}


İzci, E. \& Eroğlu, M. (2016). Eğitimde Teknoloji Kullanımı Kursu hizmetiçi eğitim programının değerlendirilmesi. International Journal of Human Sciences, 13(1), 1666-1688. doi:10.14687/ijhs.v13i1.3584

\begin{tabular}{|c|c|c|c|c|c|c|c|}
\hline Ö28 & Kadın & $1-15 \mathrm{yll}$ & Edebiyat & Ö71 & Erkek & $21-30 \mathrm{yll}$ & Edebiyat \\
\hline Ö31 & Erkek & $1-15 \mathrm{yll}$ & Edebiyat & Ö73 & Erkek & $1-15$ yll & Kimya \\
\hline Ö35 & Erkek & 30yılüstü & Meslek dersleri & Ö77 & Erkek & 21-30 yl & Rehberlik \\
\hline Ö36 & Kadın & $21-30 \mathrm{yll}$ & Tarih & Ö78 & Erkek & $1-15 \mathrm{yll}$ & Matematik \\
\hline Ö37 & Erkek & $16-20 \mathrm{yil}$ & Felsefe & Ö81 & Erkek & $21-30 \mathrm{yll}$ & Biyoloji \\
\hline Ö39 & Erkek & $1-15 \mathrm{yll}$ & Coğrafya & Ö82 & Erkek & $1-15$ yll & Din Kültürü \\
\hline Ö40 & Erkek & $21-30 \mathrm{yll}$ & Fizik & Ö84 & Kadin & $21-30 \mathrm{yll}$ & Yabancı dil \\
\hline Ö42 & Erkek & $1-15 \mathrm{yll}$ & Meslek dersleri & Ö85 & Kadin & $1-15 \mathrm{yll}$ & Yabancı dil \\
\hline Ö44 & Erkek & $1-15 \mathrm{yll}$ & Meslek dersleri & Ö86 & Erkek & $21-30 \mathrm{yll}$ & Matematik \\
\hline Ö46 & Erkek & 30yılüstü & Meslek dersleri & Ö87 & Kadin & $1-15$ yll & Yabanc1 dil \\
\hline Ö47 & Erkek & $1-15 \mathrm{yll}$ & Coğrafya & Ö89 & Erkek & $1-15 \mathrm{yll}$ & Yabanc1 dil \\
\hline
\end{tabular}

\subsection{Veri Toplama Arac1}

$\mathrm{Bu}$ çalışmada veri toplama aracı olarak anket ve görüşme formu kullanılmıştır Öğretmenlerin programın hedeflerine ne düzeyde ulaştı̆̆ını belirlemek amaciyla araştırmacı tarafindan programında yeralan kazanımlan temele alınarak taslak bir anket formu oluşturulmuştur. Programda 13 amaç belirtilmiş fakat bu amaçlar araştırmanın amacına daha iyi hizmet etmesi için kazanım ifadelerine dönüştürülmüsstür. Bu kapsamda amaçlar içerisinde bazı binişik ifadelerin yer aldığ1 gözlenmiş dolayısıyla bu ifadeler kazanım ifadesine dönüştürülürken 2 kazanım olarak ayrı ayrı yazılmışır. Bu işlemden sonra 16 maddelik taslak anket formu oluşturulmuştur. Oluşturulan bu anket formu uzman (1 Eğitim programları ve öğretim ABD'nda Öğretim üyesi, ve 1 BÖTE ABD' nda öğretim üyesi) görüşüne sunulmuştur. Gerekli görülen değişiklikler araştırmacı tarafından yapıldıktan sonra anket formuna son hali verilmiştir. Araştırmada nitel verileri toplamak amacıyla öğretmenler ve formatör öğretmenler için yarı yapılandırılmış görüşme formu kullanılmıştır. Öncelikle ilgili alan yazın taranmış ve taslak görüşme formu oluşturulmuştur. Daha sonra taslak görüşme formu uzman (1 Eğitim programları ve öğretim ABD'nda Öğretim üyesi, ve 1 BÖTE ABD' nda öğretim üyesi) görüşüne sunulmuştur. Gerekli görülen değişiklikler araştırmacı tarafindan yapıldıktan sonra anket formuna son hali verilmiştir.

\subsection{Veri Toplama Aracinın Uygulanması}

Veri toplama sürecinde araştırmacı sürece bizzat katılmıştır. Veri toplama işleminden önce katılımcılar sürece ilişkin araştırmacı tarafindan bilgilendirilmiştir. Öncelikle programın kazanımlarına ilişkin anket formunu katılımcılara uygulamışır. Anket formunu dolduran katılımcılar arasından gönüllü olanlarla görüşme yapılarak araştırmanın nitel kısmına ilişkin veri toplamıştır. Nicel ve nitel veriler eşzamanlı olarak toplanmıştır. Formatör öğretmenlerle ise yarı yapılandırılmış görüşmeler yine araştırmacı tarafindan yapılmıştır. Yarı yapılandırılmış görüşme formunda yer alan sorular araştırmacı tarafindan katılımcılara yöneltilmiştir. Görüşmeler çoğu katılımcıların isteği üzerine görüşmenin kaydedilmesi biçiminde değil de katılımcı cevaplarının araştırmacı tarafından not alınması şeklinde yapılmıştır.

\subsection{Verilerin Analizi}

Verilerin analizinde öncelikle veriler nitel ve nicel olarak gruplandırılmıştır. Nicel verilerin analizinde betimsel istatistik kullanılmıstur. Bu kapsamda ankette yer alan maddelerin ortalamaları ve standart sapmaları hesaplanmıştır. Ankette yer alan ilgili maddelere katılım düzeyini belirlemek için şu puan aralıkları baz alınmıştır: hiç katılmıyorum $=1.00-1.80$, katılmıyorum $=1.81-2.60$, kararsizım $=2.61-3.40$, katıliyorum $=3.41-, 4.20$, tamamen katıliyorum $=4.21-5.00$. Bu aralıklar baz alınarak öğretmenlerin programın kazanımlarına ne düzeyde ulaştıkları ortaya konmuştur Nitel verilerin analizinde ise içerik analizine başvurulmuştur. Bu kapsamda öncelikle görüşme formları incelenerek kodlar ve bu kodların bağlı olduğu temalar oluşturulmuştur. Temalandırma işlemi yapılırken sürekli karşılaştırma analizi yöntemi kullanılmıştır. Sürekli karşılaştırma analizi yöntemi iki 
İzci, E. \& Eroğlu, M. (2016). Eğitimde Teknoloji Kullanımı Kursu hizmetiçi eğitim programının değerlendirilmesi. International Journal of Human Sciences, 13(1), 1666-1688. doi:10.14687/ijhs.v13i1.3584

temel aşamadan oluşmaktadır. Birinci aşamada veriler okunmakta ve birbirleri ile karşılaştırılma böylece birbiriyle ilgili veriler belirli kavram ve kategoriler altında düzenlenmekte, ikinci aşamada ise kavram ve kategorilere dayalı olarak temalar oluşturulmaktadır (Have, 2004; Özdemir, 2010). Analizin her aşamasında da veriler sürekli olarak birbiriyle karşılaştırılmış benzerliklerine ve farklılıklarına gore temalandırma işlemi yapılmıştır. Temalandırma işlemi yapılırken sürekli karşılaştırmanın yanı sıra alanyazın gözönünde bulundurularak temalar oluşturulmuştur. Güvenirliği sağlamak amacıyla veriler farklı kodlayıcılar tarafindan kodlanarak kontrol kodlaması yapılmış ve kodlamalar karşılaştırılmıştır. Kontrol kodlaması sadece tanımsal netliğe yardımcı olmakla kalmaz, aynı zamanda iyi bir güvenirlik kontrolünede yardımcı olur (Miles ve Huberman, 2015). Kontrol kodlaması sonucunda araştırmada kodlanan toplam 162 koddan 11 tanesi iki araşımacı tarafindan farklı kodlanmıştır. Bu farkli kodlamalar motivasyonu arttırma, alt yap1 eksikliği, programın yetersizliği ve katulımcılardan kaynaklanan sorunlar temalarında yapılmıştır. Kontrol kodlaması sonucu araştırmacılar arasındaki görüş birliğinin hesaplanmasında Miles ve Huberman'ın (2015) belirttiği formül P (Uzlaşma Yüzdesi \%) $=[\mathrm{Na}$ (Görüş Birliği $) / \mathrm{Na}($ Görüş Birliği $)+\mathrm{Nd}($ Görüş Ayrılığı)] X 100 kullanılmıştır. Hesaplama sonucunda P = \% 93 değeri bulunarak araştırma güvenilir kabul edilmiştir. Çünkü nitel çalışmalardakodlayıcılar arasındaki görüş birliği \%90 aralığında olmalıdır(Miles ve Huberman, 2015). Bunun yanında bulgular Ö1, Ö2..... FÖ1.. FÖ3.... şeklinde isimlendirilen katılımcılardan doğrudan alıntılarla desteklenerek güvenirlik sağlanmıştır. Nitel verilerin analiz sonuçları frekans tablosu şeklinde verilmiştir. Bu araştırmada kullanılan yakınsayan paralel desen süreci destekleme ve doğrulama için, araştırmacının nicel istatistik sonuçlarını nitel bulgularla doğrudan karşılaştırması ve çeliştirmesiyle yöntemleri üçgenlemek istediği zaman kullanılır (Cresswell ve Clark, 2014). Dolayısıyla araştırmada elde edilen nicel ve nitel veriler ayrı ayrı analiz edilmiştir. Daha sonra sonuçlar ve yorumlama kısmında nicel ve nitel veriler birleştirilmiştir. Bu noktada nicel ve nitel verilerin birbirini desteklediği ve birbiriyle çeliştiği noktalar belirtilerek yorumlanmıştır. Bu şekilde veri çeşitlemesi (triangulation) yapılmıştır. Bu durum aynı zamanda araştırmanın geçerliği ve güvenirliğini güçlendirmesi bakımından önemlidir.

\section{Bulgular}

$\mathrm{Bu}$ bölümde araştırmada elde edilen nicel ve nitel verilerin analizinde elde edilen bulgulara yer verilmektedir.

\subsection{Nicel Verilere İlişkin Bulgular}

Tablo 3'de öğretmenlerin hizmetiçi eğitim programa ilişkin görüşlerine yer verilmiştir.

Tablo 3. Öğretmenlerin Hiæ̌met içi Eğitim Programma Ilișkin Görüssleri

\begin{tabular}{|c|c|c|c|}
\hline No & Maddeler & $\mathbf{X}$ & SS \\
\hline 1 & ETKK Fatih Projesinin amacını bilmemi sağladı. & 3,78 & 1,07 \\
\hline 2 & ETKK Fatih Projesinin kapsamını bilmemi sağladı. & 3,77 & 1,01 \\
\hline 3 & ETKK interneti bilinçli ve güvenli bir şekilde kullanabilmemi sağladı. & 3,52 & 1,07 \\
\hline 4 & $\begin{array}{l}\text { ETKK Fatih projesi kapsamındaki bilgi teknolojileri ekipmanlarının kurulumunu } \\
\text { yapabilmemi sağladı. }\end{array}$ & 3,21 & 1,06 \\
\hline 5 & $\begin{array}{l}\text { ETKK Fatih projesi kapsamındaki bilgi teknolojileri ekipmanlarını kullanabilmemi } \\
\text { sağladı. }\end{array}$ & 3,49 & 1,04 \\
\hline 6 & $\begin{array}{l}\text { ETKK Fatih projesi kapsamındaki Bilgi Teknolojileri ekipmanlarılla ilgili } \\
\text { karşılaşılan problemleri çözmemi sağladı. }\end{array}$ & 3,13 & 1,01 \\
\hline 7 & ETKK etkileşimli tahta yazılımlarını kullanabilmemi sağladı. & 3,49 & 1,01 \\
\hline 8 & ETKK eğitimde teknoloji kullanımına ilişkin kavramları bilmemi sağladı. & 3,51 & 0,92 \\
\hline 9 & ETKK öğretim sürecinde materyalleri yerinde kullanabilmemi sağladı. & 3,51 & 0,98 \\
\hline 10 & $\begin{array}{l}\text { ETKK Eğitim Bilişim Ağındaki materyalleri (EBA) ders sürecinde kullanabilmemi } \\
\text { sağladı. }\end{array}$ & 3,38 & 1,07 \\
\hline
\end{tabular}


11 ETKK internet üzerinde yayımlanan, ders materyallerine ulaşabilmemi sağladı. $\quad 3,51 \quad 1,04$

12 ETKK ders için seçilen materyal üzerinde değişiklikler yapabilmemi sağladı. $\quad 3,39 \quad 1,00$

13 ETKK ihtiyaç duyulan konularda materyal tasarlayabilmemi sağladi. $\quad 3,35 \quad 1,08$

14 ETKK öğretim materyalini etkili kullanmak üzere bir ders planı hazırlayabilmemi $3,48 \quad 1,09$ sağladı

15 ETKK ders planına uygun olarak etkileşimli tahta ile dersimi sunabilmemi sağladı. $\quad 3,73 \quad 0,96$

16 ETKK öğretim materyalin etkililiğini/verimliliğini değerlendirebilmemi sağladı. $\quad 3,59 \quad 0,97$

ETKK'nun kazanımlarına ilişkin öğretmenlerin görüşlerini belirlemek için hazırlanan anket maddelerinden "ETKK, FATİH Projesinin amacını bilmemi sağladı" ( $(x=3,78)$, "ETKK, FATİH Projesinin kapsamını bilmemi sağladı" ( $\mathrm{x}=3,78)$, "ETKK, ders planına uygun olarak etkileşimli tahta ile dersimi sunabilmemi sağladı" maddeleri öğretmenlerin en çok vurguladıkları ve "katıllyorum" düzeyinde görüş belirttikleri maddelerdir. Öğretmenler ETKK sayesinde FATİH projesinin amacı ve kapsamına ilişkin bilgi sahibi olduklarını ve bu kurs sayesinde etkileşimli tahta ile ders sunma konusunda bilgi ve becerilerinin geliştiğini vurgulamışlardır. Bunun yanında öğretmenler, "ETKK öğretim materyalin etkililiğini/verimliliğini değerlendirebilmemi sağladı" ( $\mathrm{x}=$ 3,59), ETKK, interneti bilinçli ve güvenli bir şekilde kullanabilmemi sağladı" $(x=3,52)$, "ETKK, eğitimde teknoloji kullanımına ilişkin kavramları bilmemi sağladı" ( $\mathrm{x}=3,51)$, "ETKK, öğretim sürecinde materyalleri yerinde kullanabilmemi sağladı" ( $(x=3,51)$, "ETKK, internet üzerinde yayımlanan, ders materyallerine ulaşabilmemi sağladı." ( $x=3,51)$, "ETKK, Fatih projesi kapsamındaki Bilgi Teknolojileri ekipmanlarını kullanabilmemi sağladı" ( $\mathrm{x}=3,49)$, "ETKK, etkileşimli tahta yazılımlarını kullanabilmemi sağladı" ( $\mathrm{x}=3,49)$, "ETKK, öğretim materyalini etkili kullanmak üzere bir ders planı hazırlayabilmemi sağladı" ( $x=3,48)$ maddelerine de "katıllyorum" düzeyinde görüş belirtmişlerdir. Öğretmenlerin en az vurguladıkları maddeler ise "ETKK, Fatih projesi kapsamındaki bilgi teknolojileri ekipmanlarıyla ilgili karşılaşılan problemleri çözmemi sağladı" $(x=3,13)$ ve "ETKK, Fatih projesi kapsamındaki bilgi teknolojileri ekipmanlarının kurulumunu yapabilmemi sağladı" ( $x=3,21)$ maddeleridir. Öğretmenler bu maddelere "kararsızım" düzeyinde görüş belirtmişlerdir. Öğretmenlerin "kararsızım” düzeyinde görüş belirttikleri diğer maddeler ise "ETKK, ihtiyaç duyulan konularda materyal tasarlayabilmemi sağladı." ( $\mathrm{x}=3,35)$, "ETKK, Eğitim Bilişim Ağındaki materyalleri (EBA) ders sürecinde kullanabilmemi sağladı" ( $\mathrm{x}=$ 3,38), "ETKK ders için seçilen materyal üzerinde değişiklikler yapabilmemi sağladı" $(x=3,39)$ maddelerdir.

\subsection{Nitel Verilere İlişkin Bulgular}

$\mathrm{Bu}$ bölümde araştırmada elde edilen nitel verilerin analizinde elde edilen bulgulara yer verilmektedir.

\subsection{1. Öğretmenlerin Programın Katkılarına İlişkin Görüşleri}

Şekil 1'de öğretmenlerin ETKK hizmetiçi eğitim programının katkılarına ilişkin görüşlerinin tematize edilmiş sonuçlarına yer verilmiştir. 
İzci, E. \& Eroğlu, M. (2016). Eğitimde Teknoloji Kullanımı Kursu hizmetiçi eğitim programının değerlendirilmesi. International Journal of Human Sciences, 13(1), 1666-1688. doi:10.14687/ijhs.v13i1.3584

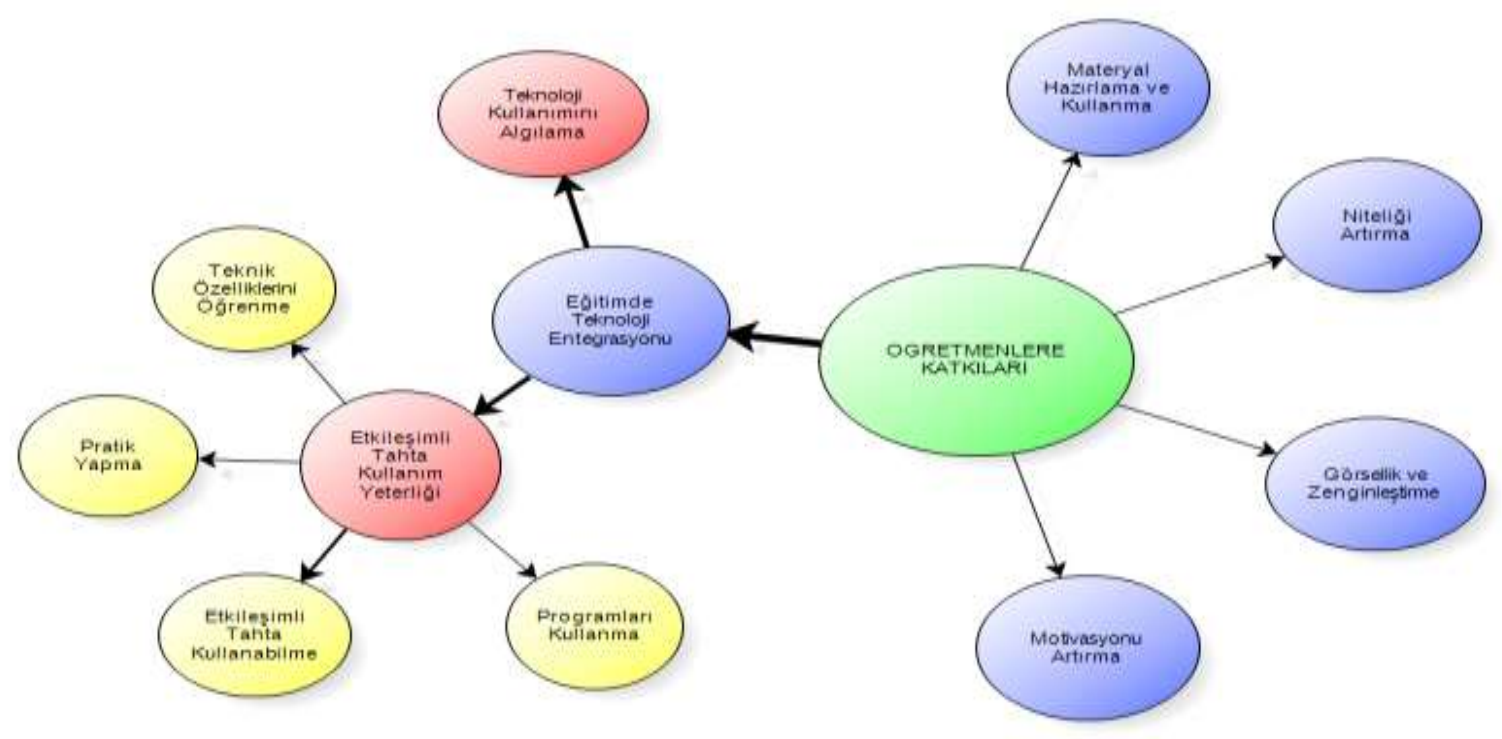

Şekil 1. Programın Katkılarına İlişkin Öğretmen Görüşleri

Tablo 4. Programm Katkılarma İlişkin Öğretmen Görüsleri

\begin{tabular}{lc}
\hline Öğretmenlere Katkıları & f \\
\hline Eğitimde Teknoloji Entegrasyonu & 37 \\
Teknoloji Kullanımını Algıllama & 19 \\
Etkileşimli Tahta Kullanım Yeterliği & 18 \\
Etkileşimli Tahta Kullanabilme & 11 \\
Teknik Özelliklerini Öğrenme & 3 \\
Programları Kullanma & 3 \\
Pratik Yapma & 1 \\
Materyal Hazırlama ve Kullanma & 4 \\
Niteliği Arturma & 6 \\
Görsellik ve Zenginleştirme & 7 \\
Motivasyonu Artırma & 5 \\
\hline
\end{tabular}

Öğretmenlerin ETKK etkinlik programının katkılarına ilişkin görüşlerinin eğitimde teknoloji entegrasyonu, materyal hazırlama ve kullanma, niteliği artırma, görsellik ve zenginleştirme ve motivasyonu artırma temaları şeklinde sınıflandığı görülmektedir. Öğretmenlerin eğitimde teknoloji kullanımı kursunun katkılarına ilişkin en çok vurguladıkları $(\mathrm{f}=37)$ tema "eğitimde teknoloji entegrasyonu" temasıdır. Eğitimde teknoloji entegrasyonu temasının da teknoloji kullanımını algılama ve etkileşimli tahta kullanım yeterliği alt temalarına ayrıldığı görülmektedir. Öğretmenlerin eğitimde teknoloji entegrasyonu teması altında en çok vurguladıkları $(\mathrm{f}=19)$ "teknoloji kullanımını algılama" alt temasıdır. Öğretmenler bu kurs sayesinde eğitimde teknoloji entegrasyonuna ilişkin bilgi ve fikir sahibi olduklarını ifade etmişlerdir. Bu alt temaya ilişkin bazı öğretmen görüşleri şu şekildedir:

Ö37: Teknolojinin eğitimde nasıl kullanulabileceğini göstermesi bakımmndan olumlu bir kurs olarak değerlendirmekteyim.

Ö39: Teknoloji entegrasyonu konusunda kismende olsa bir fikir sabibi olduk.

Ö42: Derslerimizde teknoloji kullanmaya bu kurs rebberlik etti. Takuldiğmı ve çözemediüimiz. sorulara u₹manlar tarafindan çözüm yollarm ögrendik.

Ö54: FATïH projesiyle tanısmamıฉı sağladı.

Ö68: Teknoloji ve eğitimin iç içe olmast gerektiğini ve teknolojizi sinnf içinde etkili bir şekilde kullanmam sağladr. 
İzci, E. \& Eroğlu, M. (2016). Eğitimde Teknoloji Kullanımı Kursu hizmetiçi eğitim programının değerlendirilmesi. International Journal of Human Sciences, 13(1), 1666-1688. doi:10.14687/ijhs.v13i1.3584

Öğretmenlerin eğitimde teknoloji entegrasyonu teması altında çok vurguladıkları (f=18) alt temalardan birisi "etkileşimli tahta kullanım yeterliği" alt temasıdır. Etkileşimli tahta kullanım yeterliği alt temasının da kendi içerisinde etkileşimli tahta kullanabilme, teknik özelliklerini öğrenme, programları kullanma, pratik yapma alt temalarına ayrıldığı görülmektedir. Etkileşimli tahta kullanım yeterliği alt teması altında en çok vurgulanan ( $\mathrm{f}=11)$ alt tema "etkileşimli tahta kullanabilme" alt temasıdır. Bu alt temada öğretmenler kurs sayesinde akıllı tahtayı genel özellikleriyle kullanmaya başladıklarını ifade etmişlerdir. Bu alt temaya ilişkin bazı öğretmen görüşleri şu şekildedir:

Ö1: Daba verimli ve bilinçli bir sekeilde etkilessimli tabtayı kullanmamı sağlad.

Ö40: Sistemden haberdar olmamıza ve kusmen de olsa kullanmaya baslamamıza vesile oldu.

Ö71: Bilgisayar artı, hayatımızın içinde genel olarak gerekli programları kullanabiliyoruz: Ancak

etkileşimli tabta programlarm kullanmayn bilmiyorduk. Kurs bunu ögrenmemiə⿱宀 ve gerektiği șekilde

kullanmamı̨ı sağladr.

Ö84: Bizlere sunulan akıllı tabtalar daha verimli ve bilinçli kullanmamız̨ sağlad.

Etkileşimli tahta kullanım yeterliği alt teması altında vurgulanan ( $\mathrm{f}=3$ ) alt tema "teknik özelliklerini öğrenme" alt temasıdır. Bu alt temada öğretmenler kurs sayesinde akıllı tahtanın teknik öğrendiklerini belirtmişlerdir. Bu alt temaya ilişkin bazı öğretmen görüşleri şu şekildedir:

Ö36: Akıll tabta ekipmanlarm özelliklerini fark etmemi sağladi.

Etkileşimli tahta kullanım yeterliği alt teması altında vurgulanan ( $\mathrm{f}=3$ ) diğer bir alt tema "programları kullanma" alt temasıdır. Bu alt temada öğretmenler kurs sayesinde akıllı tahta programlarını öğrendiklerini belirtmişlerdir. Bu alt temaya ilişkin bazı öğretmen görüşleri şu şekildedir:

Ö73: Baそ̌ programlar yükleme ve derslerin nasıl işleneceği konusunda katki sağlad.

Etkileşimli tahta kullanım yeterliği alt teması altında en az vurgulanan $(\mathrm{f}=1)$ alt tema "pratik yapma" alt temasıdır. Bu alt temada öğretmenler kurs sayesinde akıllı tahtaya ilişkin pratik yapma şansı bulduklarını belirtmişlerdir. Bu alt temaya ilişkin bazı öğretmen görüşleri şu şekildedir:

Ö10: Genel olarak bilgisayar kullansak ta akill tabtanm pratiği daha farkil. Bu kursla yeni ve pratik yöntemler ögrendik.

Öğretmenlerin eğitimde teknoloji kullanımı kursu etkinlik programının katkılanına ilişkin kısmen vurguladıkları $(\mathrm{f}=7)$ temalardan birisi "görsellik ve zenginleştirme" temasıdır. Bu temada ögretmenler bu kurstan edindikleri bilgilerle derslerine görsellik ve zenginlik katabildiklerini ifade etmişlerdir. Bu alt temaya ilişkin bazı öğretmen görüşleri şu şekildedir:

Ö14: Bu kurstan ögrendiklerimle renkli, şekil, grafik, gibi materyalleri sunmamı sağladi.

Ö47: Isslenen konularla ilgili harita, görseller, videolara ulaşılarak konularn daha anlaşıller olmasim sağladı.

Öğretmenlerin eğitimde teknoloji kullanımı kursu etkinlik programının katkılarına ilişkin kısmen vurguladıkları $(\mathrm{f}=6)$ temalardan birisi "niteliği artırma” temasıdır. Bu temada öğretmenler bu kurstan edindikleri bilgilerle derslerin daha verimli ve etkili olduğunu ifade etmişlerdir. Bu alt temaya ilişkin bazı öğretmen görüşleri şu şekildedir:

Ö7: Ögrretmenlerin kendilerine gelistirmelerine yardima oldu.

Ö47: Derslerin daha etkin ve verimli işlenmesini sağladl.

Öğretmenlerin eğitimde teknoloji kullanımı kursu etkinlik programının katkılarına ilişkin kısmen vurguladıkları ( $\mathrm{f}=5)$ temalardan birisi "motivasyonu artırma" temasıdır. Bu temada öğretmenler bu kurstan edindikleri bilgilerle hem kendilerinin hemde öğrencilerin motivasyonlarının arttı̆̆ını belirtmişlerdir. Bu alt temaya ilişkin bazı öğretmen görüşleri şu şekildedir:

Ö31: Ögrencilerin motivasyonlarm artırmam konusunda katkı sağladi.

Ö86: Teknolojiyi görme takip etme ve kullanma açsında bizleri egitime daha etkin bir motivasyon sağladl.

Öğretmenlerin eğitimde teknoloji kullanımı kursu etkinlik programının katkılarına ilişkin kısmen vurguladikları $(\mathrm{f}=4)$ temalardan birisi "materyal hazırlama ve kullanma" temasıdır. $\mathrm{Bu}$ temada öğretmenler bu kurstan edindikleri bilgilerle materyal hazırlama ve kullanma konusunda tecrübelerinin ve seçeneklerinin arttığını ifade etmişlerdir. Bu alt temaya ilişkin bazı öğretmen 
İzci, E. \& Eroğlu, M. (2016). Eğitimde Teknoloji Kullanımı Kursu hizmetiçi eğitim programının değerlendirilmesi. International Journal of Human Sciences, 13(1), 1666-1688. doi:10.14687/ijhs.v13i1.3584

görüşleri şu şekildedir:

Ö57: Materyallerin kullanmmin ve elde edilmesini kolaylasstord.

Ö69: Ders materyallerinin hažrlanması sunumu imkanu sağlad.

\subsection{2. Öğretmenlerin Programdaki Aksaklıklar ve Sorunlara İlişkin Görüşleri}

Şekil 2'de öğretmenlerin ETKK hizmetiçi eğitim programındaki aksaklıklar ve sorunlara ilişkin görüşlerinin tematize edilmiş sonuçlarına yer verilmiştir.



Şekil 2. Programdaki Aksaklıklara ve Sorunlara İlişkin Öğretmen Görüşleri

Tablo 5. Programdaki Aksaklıklara ve Sorunlara İliskin Ögretmen Görüsleri

\begin{tabular}{lc}
\hline Aksaklıklar ve Sorunlar & f \\
\hline Eğitmen Niteliği & 4 \\
Pratik Eksikliği & 15 \\
Altyap1 Eksikliği & 17 \\
Teknik Sorunlar ve Ekipman Eksikliği & 10 \\
Doküman Eksikliği & 5 \\
Ortamin Yetersizliği & 2 \\
Zaman Sorunları & 28 \\
Uygunsuz Kurs Zamanı & 13 \\
Yetersiz Süre & 15 \\
Ögretmenlerin Özellikleri & 5 \\
Yetersiz Hazırbulunuşluk & 3 \\
İsteksizlik & 2 \\
\hline
\end{tabular}

Öğretmenlerin ETKK etkinlik programındaki aksaklıklara ve sorunlara ilişkin görüşlerinin eğitmen niteliği, pratik eksikliği, alt yap1 eksikliği, zaman sorunları, öğretmenlerin özellikleri temaları şeklinde sınıflandığı görülmektedir. Öğretmenlerin ETKK programındaki aksaklıklara ve sorunlara en çok vurguladıkları $(\mathrm{f}=28)$ tema "zaman sorunları" temasıdır. Zaman sorunları teması da yetersiz süre, uygunsuz kurs zamanı alt temalarına ayrıldığı görülmektedir. Öğretmenler zaman sorunları teması altında en çok vurguladıkları $(\mathrm{f}=15)$ "yetersiz süre” alt temasıdır. Öğretmenler, bu kurs için ayrılan zamanın yetersiz olduğunu belirtmişlerdir. Bu alt temaya ilişkin bazı öğretmen görüşleri şu şekildedir:

Ö66: Kurs sayısımm ve zamanmm artmlmasi gerektiğini düsünüyorum.

Ö68: Kurs zaman bakimmian eksik kalyyor. Internet ve uzaktan eğitimle bu eksiklik giderilebilir.

Ö81: Zaman yetersiz olduğundan konular hiz̨l ilerledi ve bazı konular eksik. kald.

Ö82: Kursun eksik yanlar çok kusa süre içinde her şeyi ögrenmeye calısmaktır.

Öğretmenlerin zaman sorunları teması altında çok vurguladıkları $(f=15)$ diğer alt tema ise “uygunsuz kurs zamanı” alt temasıdır. Öğretmenler, kursun yapıldığı zamanın uygun olmadığını 
İzci, E. \& Eroğlu, M. (2016). Eğitimde Teknoloji Kullanımı Kursu hizmetiçi eğitim programının değerlendirilmesi. International Journal of Human Sciences, 13(1), 1666-1688. doi:10.14687/ijhs.v13i1.3584

ders saatleriyle çakıştı̆̆ıı ifade etmişlerdir. Bu alt temaya ilişkin bazı öğretmen görüşleri şu şekildedir:

Ö12: Öğretmen dersteykeen kurslarn başlaması bu kurslardan istenen verimin alnmasın engelledi.

Ö31: Kurs zaman ders bitimi sonrası olmasi yorgunluktan dolayn verimi düsürï̈or.

Ö42: Kursun verildiği dönemde kurs saatlerinin baž ögretmenlerin programlarm aksatmasma sebep oldu.

Ö85: Bayan olarak zamanlamanın problem olduğunu düş̈nüyorum. Okul sonrası açılan kurs zihnimizin evde olmasina neden oluyor. Mesai saatleri içinde yapullrsa daha uygun olurdu.

Öğretmenlerin ETKK programındaki aksaklıklara ve sorunlara çok vurguladıkları $(\mathrm{f}=28)$ tema "alt yap1 eksikliği” temasıdır. Alt yap1 eksikliği teması da teknik sorunlar ve ekipman eksikliği, doküman eksikliği, ortamın yetersizliği alt temalarına ayrıldığı görülmektedir. Öğretmenler alt yap1 eksikliği teması altında en çok vurguladıkları $(\mathrm{f}=10)$ "teknik sorunlar ve ekipman eksikliğı" alt temasıdır. Öğretmenler, bu tema altında kurs sırasında teknik konular ve ekipman eksikliği gibi sorunlarla karşılaştkklarını belirtmişlerdir. Bu alt temaya ilişkin bazı öğretmen görüşleri şu şekildedir:

Ö12: En önemlisi akıllh tabtalar kurulumu tamamlamadan kurslar verilmeye başland.

Ö1: Ekipmanlar iyi olmadiğndan dolayn kurs verimli olmadl.

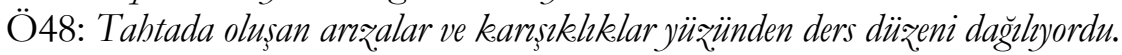

Öğretmenler alt yap1 eksikliği teması altında kısmen vurguladıkları (f=5) "doküman eksikliğı” alt temasıdır. Öğretmenler, bu tema altında kurs sırasında özellikle her branşa ilişkin dokümanların olmadığını belirtmişlerdir. Bu alt temaya ilişkin bazı formatör öğretmen görüşleri şu şekildedir:

Ö35: Kuranı kerim hariç diğer derslerle ilgili gerekli dokümanlar yükklenmemisti.

Ö78: Yeterince doküman ve ders uygulamalarnm olmaması. EBA' nin yetersiz olmast.

Öğretmenler alt yapı eksikliği teması altında en az vurguladıkları ( $f=2)$ "ortamın yetersizliğı" alt temasıdır. Öğretmenler, bu tema altında kursların yapıldığı ortamların özellikle fiziki yetersizliklerini ifade etmişlerdir. Bu alt temaya ilişkin bazı öğretmen görüşleri şu şekildedir:

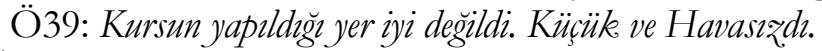

Öğretmenlerin ETKK programındaki aksaklıklara ve sorunlara ilişkin çok vurguladıkları $(\mathrm{f}=15)$ temalardan birisi de "pratik eksikliği”" temasıdır. Öğretmenler, bu tema altında kurs sırasında öğrendiklerine ilişkin yeterli pratik yapamadıklarını ifade etmişlerdir. $\mathrm{Bu}$ alt temaya ilişkin bazı öğretmen görüşleri şu şekildedir:

Ö37: Verilen kurs içerik olarak yeterli olmasma rağmen, uygulamalarn yetersiz. kaldiğmn düsünüyorum.

Ö50: Eksik olarak daha çok pratik yapulabilirdi.

Ö57: Kursta yeterli pratik yapamadiğımı̨dan derslerde yaptığımı uygulamalar çok zaman alyyor.

Müfredatc yetistiremiyorur:

Ö89: Uygulama sayısinin az olmast ve alanma ilişkin uygulama yapılmaması eksiklikti.

Öğretmenlerin ETKK programındaki aksaklıklara ve sorunlara ilişkin kısmen vurguladıkları $(\mathrm{f}=5)$ temalardan birisi “öğretmen özellikleri” temasıdır. Öğretmen özellikleri teması da yetersiz hazırbulunuşluk ve isteksizlik alt temalarına ayrıldığı görülmektedir. Öğretmenler öğretmen özellikleri teması altında en çok vurguladıkları $(\mathrm{f}=3)$ "yetersiz hazırbulunuşluk" alt temasıdır. Öğretmenler, bu tema altında kurs sırasında katılımcı öğretmenlerin yeterli hazır bulunuşluklarının olmamasının kursu olumsuz etkilediğini ifade etmişlerdir. Bu alt temaya ilişkin öğretmen görüşleri şu şekildedir:

Ö77: Gruplar daba bomojen olmalyydı bilgisayarn asmayn bilmeyenlerle belli düzeyde bilen ayn kursta olmamal.

Öğretmenler öğretmen özellikleri teması altında az vurguladıkları ( $\mathrm{f}=2$ ) “isteksizlik" alt temasıdır. Öğretmenler, bu tema altında kurs sırasında katllımcı öğretmenlerin isteksiz davranışlarının kursu olumsuz etkilediğini ifade etmişlerdir. Bu alt temaya ilişkin öğretmen görüşleri şu şekildedir: 
İzci, E. \& Eroğlu, M. (2016). Eğitimde Teknoloji Kullanımı Kursu hizmetiçi eğitim programının değerlendirilmesi. International Journal of Human Sciences, 13(1), 1666-1688. doi:10.14687/ijhs.v13i1.3584

Ö7: İsteksiz ögretmenlere ₹orla eğitim verildiğini düss̈nülürse bu durumun verimi düsürdügünü dïsünüyorum.

Öğretmenlerin ETKK programındaki aksaklıklara ve sorunlara ilişkin kısmen vurguladıkları $(\mathrm{f}=4)$ temalardan birisi "eğitmen niteliğ̣" temasıdır. Öğretmenler, bu tema altında kurs eğitmenlerinin yetersizlĭgi belirtmişlerdir. Bu alt temaya ilişkin öğretmen görüşleri şu şekildedir:

Ö35: Ë̆itmenlerin konuya vakuf olmamalar ve yüzeysel gecmeleri. Ë̈itmenlerin Öğretmenlerin akıll tabtayla ilk defa karşllaştıklarm unutup üstün körü anlatmalar nitelig̈i düssürdüi.

Ö7: Eğitmenlerden bazlarl yetersizdi.

\subsubsection{Formatör Öğretmenlerin Programın Katkılarına İlişkin Görüşleri}

Şekil 3'de formatör öğretmenlerin ETKK hizmetiçi eğitim programının öğretmenlere katkılarına ilişkin görüşlerinin tematize edilmiş sonuçlarına yer verilmiştir.

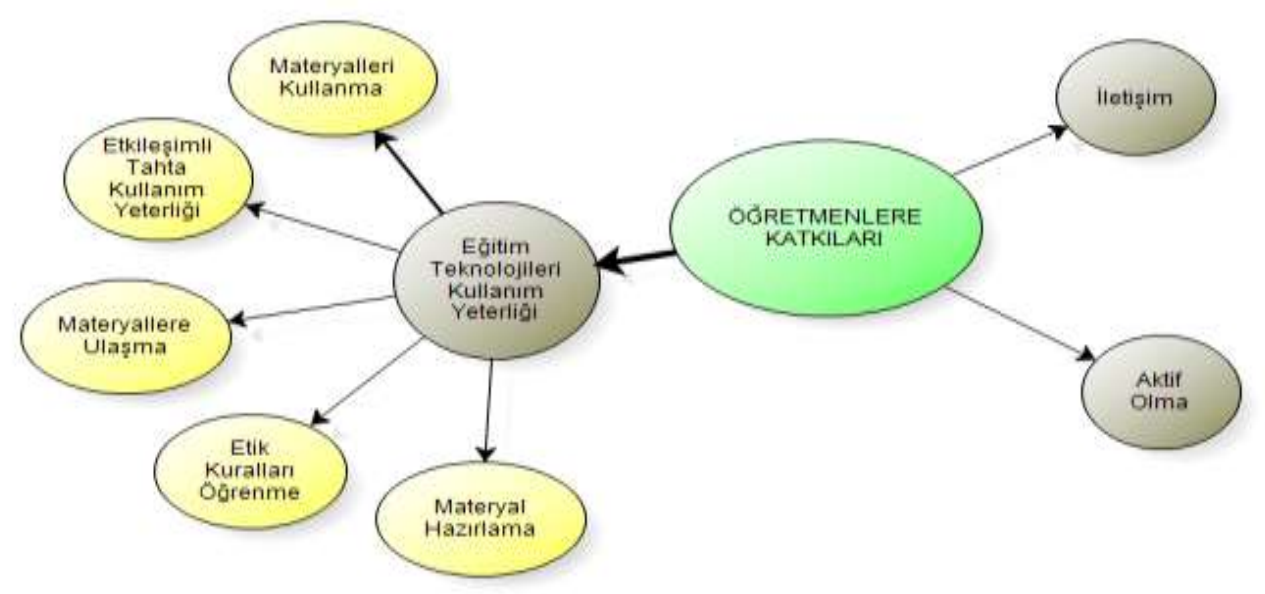

Şekil 3. Programın Katkılarına İlişkin Formatör Öğretmen Görüşleri

Tablo 6. Programm Katkelarna Ilişkin Formatör Öğretmen Görüsleri

\begin{tabular}{lc}
\hline Öğretmenlere Katkıları & f \\
\hline Eğitim Teknolojileri Kullanım Yeterliği & 8 \\
Etkileşimli Tahta Kullanım Yeterliği & 2 \\
Materyal hazırlama & 1 \\
Materyallere Ulaşma & 1 \\
Materyalleri Kullanma & 3 \\
Etik Kuralları Öğrenme & 1 \\
İletissim & 1 \\
Aktif Olma & 2 \\
\hline
\end{tabular}

Formatör öğretmenlerin ETKK etkinlik programının öğretmenlere katkılarına ilişkin görüşlerinin eğitim teknolojileri kullanım yeterliği, iletişim ve aktif olma temaları şeklinde sınıflandığ1 görülmektedir. Formatör ETKK'nun öğretmenlere katkılarına ilişkin en çok vurguladıkları ( $\mathrm{f}=8$ ) tema "eğitim teknolojileri kullanım yeterliği”" temasıdır. Eğitim teknolojileri kullanım yeterliği temasının da etkileşimli tahta kullanım yeterliği, materyal hazırlama, materyallere ulaşma, materyalleri kullanma, etik kuralları öğrenme alt temalarına ayrıldığı görülmektedir. Formatör öğretmenler kursun katkılarına ilişkin en çok vurguladıkları ( $\mathrm{f}=3$ ) alt tema "materyalleri kullanma" alt temasıdır. Formatör öğretmenler, öğretmelerin bu kurs sayesinde öğretim materyallerini daha etkili bir şekilde kullanabildiklerini ifade etmişlerdir. Bu alt temaya ilişkin bazı formatör öğretmen görüşleri şu şekildedir:

FÖ2: pdf, video, resim vb gibi materyalleri derslerine göre düzenleyip kullanmayı ögreniyorlar. 
İzci, E. \& Eroğlu, M. (2016). Eğitimde Teknoloji Kullanımı Kursu hizmetiçi eğitim programının değerlendirilmesi. International Journal of Human Sciences, 13(1), 1666-1688. doi:10.14687/ijhs.v13i1.3584

Formatör öğretmenlerin eğitim teknolojileri kullanım yeterliği teması altında vurguladıkları $(\mathrm{f}=2)$ diğer bir tema ise "etkileşimli tahta kullanım yeterliğı" alt temasıdır. Formatör öğretmenler, öğretmenlerin bu kurs sayesinde etkileşimli tahta kullanımı konusunda yeterlik sağladıklarını ifade etmişlerdir. Bu alt temaya ilişkin bazı formatör öğretmen görüşleri şu şekildedir:

FÖ4: Günümüzde eğitimde teknoloji kullanmm neredeyse zorunlu bale gelmiştir. Bu bižnetiçi eğitim kursuda özellikle ögretmenlerin yeni bir eğitim teknolojisi olan akıllh tabtalarn kullanmmna ilişkin becerileri kazanmasm sağlamaktadır.

Formatör öğretmenlerin eğitim teknolojileri kullanım yeterliği teması altında az vurguladıklanı ( $\mathrm{f}=2$ ) diğer bir tema ise "materyal hazırlama" alt temasıdır. Formatör öğretmenler, ögrretmenlerin bu kurs sayesinde materyal hazırlama konusunda bilgi ve becerilerini geliştirdiklerini belirtmişlerdir. Bu alt temaya ilişkin bazı formatör öğretmen görüşleri şu şekildedir:

FÖ2: Materyal hazurlama yeterliliğine sahip oluyorlar.

Formatör öğretmenlerin eğitim teknolojileri kullanım yeterliği teması altında az vurguladıkları ( $\mathrm{f}=1$ ) diğer bir tema ise "materyallere ulaşma" alt temasıdır. Formatör öğretmenler, öğretmenlerin bu kurs sayesinde materyal ulaşma konusunda bilgi ve becerilerini geliştirdiklerini belirtmişlerdir. Bu alt temaya ilişkin formatör öğretmen görüşü şu şekildedir:

FÖ2: $p d f$, video, resim vb gibi materyalleri internet üzerinden bulabiliyorlar.

Formatör öğretmenlerin eğitim teknolojileri kullanım yeterliği teması altında az vurguladıkları ( $\mathrm{f}=1$ ) diğer bir tema ise "etik kuralları ögrenme" alt temasıdır. Formatör öğretmenler, ögretmenlerin bu kurs sayesinde materyallerin ve kaynakların kullanımına ilişkin telif hakkı gibi etik kuralları öğrendiklerini belirtmişlerdir. Bu alt temaya ilişkin formatör öğretmen görüşü şu şekildedir:

FÖ2: Ayrica bu tür materyaller için telif hakekmm önemini kavryorlar.

Formatör öğretmenlerin ETKK'nun öğretmenlere katkılarına ilişkin vurguladıklanı ( $\mathrm{f}=2)$ temalardan biri "aktif olma" temasıdır. Bu temada formatör öğretmenler, bu kursun katkılarıyla ögrretmenlerin derslerinde daha aktif olduklarını ifade etmişlerdir. Bu alt temaya ilişkin formatör öğretmen görüşü şu şekildedir:

FÖ3: Ögrretmen arkadaşlarmıฉ̨n derslerinde daha aktif olmalarm sağlamaktadır.

Formatör öğretmenlerin ETKK'nun öğretmenlere katkılarına ilişkin en az vurguladıkları $(\mathrm{f}=1)$ tema "iletişim" temasıdır. Bu temada formatör öğretmenler, öğretmenlerin bu kurs sayesinde teknolojiyi daha etkin kullanabildiklerinden öğrenciyle daha iyi iletişim kurabildiğini ifade etmişlerdir. Bu alt temaya ilişkin formatör öğretmen görüşü şu şekildedir:

FÖ3: Öğretmenlerin teknolojïye daha yakın olmalarm sağlamaktadırlar. Böylece ögrrenciyle de daha iyi iletisim kurabilmektedirler.

\subsubsection{Formatör Öğretmenlerin Programdaki Aksaklıklar ve Sorunlara İlişkin Görüşleri}

Aşağıda formatör öğretmenlerin ETKK etkinlik programdaki aksaklıklar ve sorunlara ilişkin görüşlerinin tematize edilmişs sonuçlarına yer verilmiştir.

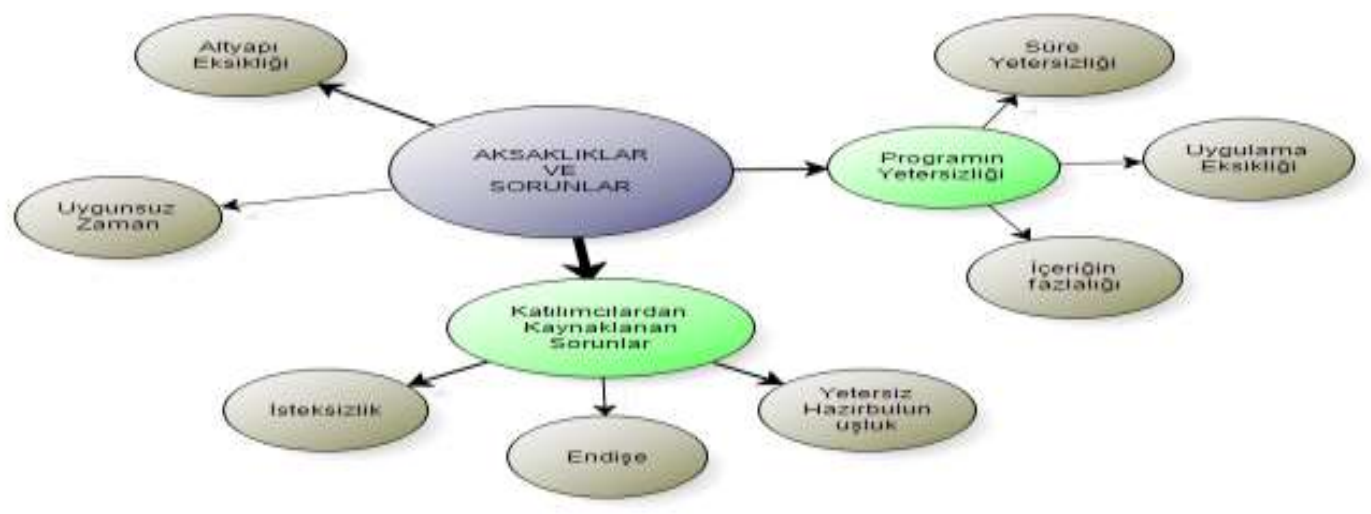

Şekil 4. Programdaki Aksaklıklara ve Sorunlara İlişkin Formatör Öğretmen Görüşleri 
İzci, E. \& Eroğlu, M. (2016). Eğitimde Teknoloji Kullanımı Kursu hizmetiçi eğitim programının değerlendirilmesi. International Journal of Human Sciences, 13(1), 1666-1688. doi:10.14687/ijhs.v13i1.3584

Tablo 7. Programdaki Aksakllklara ve Sorunlara Iliş̧kin Formatör Ögretmen Görüsleri

\begin{tabular}{lc}
\hline Aksaklıklar ve Sorunlar & f \\
\hline Alt Yapı Eksikliği & 4 \\
Uygunsuz Zaman & 1 \\
Programın Yetersizliği & 5 \\
Süre Yetersizliği & 1 \\
Uygulama Eksikliği & 2 \\
İçeriğin Fazlalı̆̆1 & 2 \\
Katılımcılardan Kaynaklanan Sorunlar & 13 \\
Yetersiz Hazırbulunuşluk & 4 \\
İsteksizlik & 7 \\
Endişe & 2 \\
\hline
\end{tabular}

Formatör öğretmenlerin ETKK etkinlik programındaki aksaklıklara ve sorunlara ilişkin görüşlerinin katılımcılardan kaynaklanan sorunlar, programın yetersizliği, alt yapı eksikliği, uygunsuz zaman temaları şeklinde sinıflandığı görülmektedir. Formatör öğretmenlerin eğitimde teknoloji kullanımı kursu programındaki aksaklıklara ve sorunlara en çok vurguladıkları ( $\mathrm{f}=13$ ) tema "katılımcilardan kaynaklanan sorunlar" temasidır. Katılımcilardan kaynaklanan sorunlar temas1 da yetersiz hazırbulunuşluk, isteksizlik, endişe, alt temalarına ayrıldığı görülmektedir. Formatör öğretmenler katılımcılardan kaynaklanan sorunlar teması altında en çok vurguladıkları $(\mathrm{f}=7)$ "isteksizlik" alt temasıdır. Formatör öğretmenler, öğretmelerin bu kursta isteksiz davrandıklarını belirtmişlerdir. Bu alt temaya ilişkin bazı formatör öğretmen görüşleri şu şekildedir:

FÖ1: Ögretmenlerin kurs zamannda erken çlkmak istemesi veya devamsızllk yapmak istemesi sorun yaratiyor.

FÖ2: Bazen ögretmenlerin kursu ekstra bir iş olarak algulamalar ve bu nedenle isteksiz olmalar.

Formatör öğretmenler katılımcılardan kaynaklanan sorunlar teması altında çok vurguladıkları $(\mathrm{f}=4)$ "yetersiz hazırbulunuşluk" alt temasıdır. Formatör öğretmenler, öğretmelerin hazır bulunuşluklarının bu kurs için yeterli olmadığını ifade etmişlerdir. Bu alt temaya ilişkin formatör öğretmen görüşü şu şekildedir:

FÖ2: Baž ögretmenler teknoloji konusunda gerçekten çok yetersiz, kalabiliyor, onlara önce bilgisayarn mantiğm kavratmake gerekiyor ki sonrasinda akull tabta ve e-doküman düzenleme konusunda fikir ve beceri sabibi olsun.

Formatör öğretmenler katılımcılardan kaynaklanan sorunlar teması altında az vurguladıkları $(\mathrm{f}=2)$ "endişe" alt temasıdır. Formatör öğretmenler, öğretmelerin bu kursta teknoloji kullanımı konusunda endişe yaşadıklarını belirtmişlerdir. Bu alt temaya ilişkin formatör öğretmen görüşü şu şekildedir:

FÖ4: Öğretmenlerin derslerde akill tabta kullantrken ürkek davranmalar.

Formatör öğretmenlerin ETKK programındaki aksaklıklara ve sorunlara çok vurguladıkları (f=13) temalardan biri "programın yetersizliği" temasıdır. Programın yetersizliği teması da süre yetersizliği, uygulama eksikliği, içeriğin fazlalı̆̆1 alt temalarına ayrıldığ1 görülmektedir. Formatör ögretmenler programın yetersizliği teması altında vurguladıkları $(\mathrm{f}=2)$ temalardan biri "uygulama eksikliği" alt temasıdır. Formatör öğretmenler, bu kursta yapılan uygulama sayısının yetersiz olduğunu ifade etmişlerdir. Bu alt temaya ilişkin formatör öğretmen görüşü şu şekildedir:

FÖ1: Kursta daha çok uygulama yapturlmasi gerekiyor.

Formatör öğretmenler programın yetersizliği teması altında vurguladıkları ( $\mathrm{f}=2$ ) temalardan biri "İçeriğin fazlalığı" alt temasıdır. Formatör öğretmenler, bu kursun içeriğinin çok fazla olduğunu ifade etmişlerdir. Bu alt temaya ilişkin formatör öğretmen görüşü şu şekildedir:

FÖ1: Kurstaki teorik kisım çok fað̧la 
İzci, E. \& Eroğlu, M. (2016). Eğitimde Teknoloji Kullanımı Kursu hizmetiçi eğitim programının değerlendirilmesi. International Journal of Human Sciences, 13(1), 1666-1688. doi:10.14687/ijhs.v13i1.3584

Formatör öğretmenler programın yetersizliği teması altında en az vurguladıkları $(\mathrm{f}=1)$ tema "süre yetersizliği" alt temasıdır. Formatör öğretmenler, bu kurs için ayrılan sürenin yetersiz olduğunu ifade etmişlerdir. Bu alt temaya ilişkin formatör öğretmen görüşü şu şekildedir:

FÖ2: Süresi biraz daba uzun olabilir. Ç̈̈nkü baz̨ ögretmenler teknoloji konusunda gerçekten çok yetersiz kalabiliyor, onlara önce bilgisayann mantiğm kavratmak gerekiyor ki sonrasinda akıllh tahta ve e-doküman düzenleme konusunda fikir ve beceri sabibi olsun.

Formatör öğretmenlerin ETKK programındaki aksaklıklara ve sorunlara ilişkin çok vurguladıkları ( $\mathrm{f}=4)$ temalardan biri "alt yapı eksikliugiı" temasıdır. Formatör öğretmenler, bu kurs için alt yapının yetersiz olduğunu ifade etmişlerdir. Bu alt temaya ilişkin bazı formatör öğretmen görüşleri şu şekildedir:

FÖ2: Kurslarn verildigi baž laboratuvardaki bilgisayarlar çok eski olabiliyor ya da internet yavaș kalabiliyor.

FÖ4: Kurs içeriğinde kullanulan programin yetersiz olmasi.

Formatör öğretmenlerin ETKK programindaki aksaklıklara ve sorunlara ilişkin en az vurguladıkları $(\mathrm{f}=1)$ tema "uygunsuz zaman" temasıdır. Formatör öğretmenler, kurs saatlerinin katılımcılar için uygun olmadığını belirtmişlerdir. Bu alt temaya ilişkin formatör öğretmen görüşü şu şekildedir:

FÖ4: Kurs saatinin derslerle çakıısması olumsuz bir yönüdür.

\section{SONUÇLAR, TARTIŞMA ve ÖNERİLER}

Bu bölümde çalışmada elde edilen sonuçlara, tartşmaya ve önerilere yer verilecektir.

\subsection{Nicel Verilere İlişkin Sonuçlar}

ETKK'nun kazanımlarına ilişkin öğretmenlerin görüşlerini belirlemek için hazırlanan anket maddelerinin çoğuna öğretmenlerin "katıllyorum" düzeyinde görüş belirttikleri bir kısmına ise "kararsızım" düzeyinde görüş belirttikleri belirlenmiştir. Öğretmenler, FATİH projesinin amacını ve kapsamını bilme, öğretim materyalinin verimini değerlendirme, interneti bilinçli kullanma, eğitimde teknoloji kullanımına ilişkin kavramlan bilme, öğretim sürecinde materyalleri yerinde kullanabilme, FATİH projesi kapsamındaki ekipmanları kullanabilme, etkileşimli tahta yazılımlanını kullanabilme gibi kazanımlara katılıyorum düzeyinde görüş belirtmişlerdir. Bunun yanında bilgi teknolojileri ekipmanlarıyla ilgili karşılaşılan problemleri çözme, bilgi teknolojileri ekipmanlarının kurulumunu yapabilme, materyal tasarlayabilme, EBA (Eğitim Bilişsim Ağı)'yı ekili kullanabilme, materyal üzerinde değişiklik yapabilme kazanımlarına "kararsızım" düzeyinde görüş belirtmişlerdir. Kazanımlara ulaşma konusunda öğretmenler genel olarak olumlu görüş belirtmelerine rağmen bazı kazanımlar konusunda kısmen sıkıntıların yaşandı̆̆ı da görülmektedir. Bu bağlamda özellikle materyal tasarlayabilme ve EBA'y1 etkili kullanabilme kazanımlarının üzerinde durulması gerekmektedir. Ekipmanların kurulumun yapılabilmesi, ekipmanlarla ilgili karşılaşılan sorunların giderilmesi gibi durumlar ise teknik personelden destek alınarak da yapılabilir. Fakat materyal tasarlama ve EBA'yı etkili kullanma gibi kazanımlara öğretmenlerin ulaşmış olması beklenmektedir.

\subsection{Nitel Verilere İlişkin Sonuçlar}

Öğretmenlerin ETKK hizmetiçi eğitim programının katkılarına ilişkin görüşlerinin eğitimde teknoloji entegrasyonu, materyal hazırlama ve kullanma, niteliği artırma, görsellik ve zenginleștirme ve motivasyonu artırma temaları şeklinde sınıflandığı görülmektedir. Öğretmenlerin ETKK'nun katkılarına ilişkin en çok vurguladıkları tema "eğitimde teknoloji entegrasyonu" temasıdır. Öğretmenlerin ETKK etkinlik programının katkılarına ilişkin görüşlerinin kursun kazanımlarıyla paralel olarak özellikle eğitimde teknoloji kullanımı, etkileşimli tahta kullanımı, materyal hazırlama ve kullanma gibi özelliklerin ön plana çıktığı görülmektedir. Dolayısıyla bu sonuçlar araştırmanın nicel kısmindaki bulgularla paraleldir.

Öğretmenlerin ETKK hizmetiçi eğitim programındaki aksaklıklara ve sorunlara ilişkin görüşlerinin eğitmen niteliği, pratik eksikliği, alt yap1 eksikliği, zaman sorunları, öğretmenlerin 
İzci, E. \& Eroğlu, M. (2016). Eğitimde Teknoloji Kullanımı Kursu hizmetiçi eğitim programının değerlendirilmesi. International Journal of Human Sciences, 13(1), 1666-1688. doi:10.14687/ijhs.v13i1.3584

Özellikleri temaları şeklinde sınıflandığı görülmektedir. Öğretmenlerin kurs programındaki aksaklıklara ve sorunlara ilişkin en çok vurguladıkları tema "zaman sorunları" temasıdır. Bu bağlamda öğretmenler kurs süresinin yetersizliğini ve kendileri için uygun olmayan zamanda yapıldığını bu nedenle yeterince yararlanamadıklarını belirtmişlerdir. Öğretmenlerin kurs programındaki aksaklıklara ve sorunlara ilişkin çok vurguladıkları temalardan biri "alt yapı eksikliği’" temasıdır. Bu bağlamda öğretmenler teknik sorunlar, ekipman eksikliği, doküman eksikliği ve uygun olmayan fiziki ortama vurgu yapmışlardır. Öğretmenlerin kurs programındaki aksaklıklara ve sorunlara ilişkin çok vurguladıkları temalardan birisi de pratik eksikliği temasıdır. Bu bağlamda öğretmenler özellikte kursta yeterli pratik yapamadıklarını ifade etmişlerdir. Öğretmenlerin kurs programındaki aksaklıklara ve sorunlara ilişkin kısmen vurguladıkları temalardan birisi öğretmen özellikleri temasıdır. Bu bağlamda öğretmenler, katılımcıların yetersiz hazırbulunuşluğu ve isteksizliğini vurgulamışlardır. Bu sonuç programın aksaklıklarına ve sorunlara ilişkin formatör öğretmenlerin görüşleriyle paraleldir. Öğretmenlerin kurs programındaki aksaklıklara ve sorunlara ilişkin kısmen vurguladıkları temalardan birisi "eğitmen niteliği”" temasıdır. Öğretmenler kurs eğitmenlerin yeterli olmadığını ifade etmişlerdir. Dolayısıyla araştırmanın nicel kısmındaki materyal hazırlama, tasarlama, düzenleme, karşılaşılan sorunları çözme, EBA'yı kullanabilme gibi bazı kazanımlara ulaşma düzeylerinin nitel kısımda vurgu yaptıkları alt yap1 eksikliği, pratik eksikliği, zaman sorunları, öğretmen özellikleri, eğitmen niteliği temalarıyla ilişkili olduğu düşünülebilir.

Formatör öğretmenlerin ETKK hizmetiçi etkinlik programının öğretmenlere katkılarına ilişkin görüşlerinin, eğitim teknolojileri kullanım yeterliği, iletişim ve aktif olma temaları şeklinde sınıflandığ1 görülmektedir. Formatör öğretmenlerin eğitimde teknoloji kullanımı kursunun öğretmenlere katkılarına ilişkin en çok vurguladıkları tema "eğitim teknolojileri kullanım yeterliğı" temasıdır. Eğitim teknolojileri kullanım yeterliği temasının da etkileşimli tahta kullanım yeterliği, materyal hazırlama, materyallere ulaşma, materyalleri kullanma, etik kuralları öğrenme alt temalarına ayrıldığ1 görülmektedir. Formatör öğretmenler, etkileşimli tahta kullanımı yeterliği, materyal hazırlama materyale ulaşma ve etik kuralları öğrenme noktasında kursun öğretmenlere katk1 yaptığını belirtmişlerdir. Bunun yanında bu kurs sayesinde derste aktif olma ve iletişim gibi becerilerini de geliştirdiklerini belirtmişlerdir. Formatör öğretmenlerin kursun katkılarına ilişkin görüşleri kursun kazanımlarıyla paralellik göstermektedir. Bu bağlamda etkileşimli tahta kullanımı ön plana çıkmaktadır.

Formatör öğretmenlerin ETKK etkinlik programındaki aksaklıklara ve sorunlara ilişkin görüşlerinin katılımcılardan kaynaklanan sorunlar, programın yetersizliği, alt yapı eksikliği, uygunsuz zaman temaları şeklindedir. Formatör öğretmenlerin en çok vurguladıkları tema "katılımcılardan kaynaklanan sorunlar" temasıdır. Bu bağlamda formatör öğretmenler, katılımcı öğretmenlerin kursa ilişkin yetersiz hazırbulunuşluğu, isteksizliği, endişeleri vurgulanmıştır. Formatör öğretmenlerin kurs programındaki aksaklıklara ve sorunlara çok vurguladıkları temalardan biri "programın yetersizliği”" temasıdır. Bu bağlamda formatör öğretmenler, kursun süresinin yetersizliği, uygulama eksikliği, kurs içeriğinin fazlalığına ilişkin görüş belirtmişlerdir. Formatör öğretmenlerin ETKK programındaki aksaklıklara ve sorunlara ilişkin kısmen vurguladıkları temalardan biri "alt yapı eksikliği”" temasıdır. Formatör öğretmenlerin ETKK programındaki aksaklıklara ve sorunlara ilişkin en az vurguladıkları tema "uygunsuz zaman" temasıdır. Formatör öğretmenlerin ETKK etkinlik programındaki aksaklıklara ve sorunlara ilişkin görüşleri incelendiğinde katılımcı öğretmenlerden kaynaklanan sorunları daha çok vurguladıkları, bunun yanında programın yetersizliğine ve alt yapı sorunlarına da kısmen vurgu yaptıkları belirlenmiştir.

Formatör öğretmenlerin ETKK etkinlik programının katkılarına ilişkin görüşlerinde eğitim teknolojileri kullanım yeterliğinin ön plana çıktığı bunun yanında iletişim ve aktif olma gibi noktalara da vurgu yapıldığ 1 belirlenmiştir. Formatör öğretmenlerin kursun katkılarına ilişkin görüşlerinin kursun kazanımlarıla paralel olduğu söylenebilir. Formatör öğretmenlerin ETKK etkinlik programındaki eksiklere ve sorunlara ilişkin görüşlerinde ise katılımcılardan kaynaklanan sorunlar, programın yetersizliği, alt yapı eksikliği ve uygunsuz zaman konularının daha çok vurgulandığ1 belirlenmiştir. Bu bağlamda kursun aksaklıklarına ve sorunlara ilişkin formatör öğretmenlerin ve 
İzci, E. \& Eroğlu, M. (2016). Eğitimde Teknoloji Kullanımı Kursu hizmetiçi eğitim programının değerlendirilmesi. International Journal of Human Sciences, 13(1), 1666-1688. doi:10.14687/ijhs.v13i1.3584

öğretmenlerin özellikle kurs saati konusuna ortak vurgu yaptıkları görülmektedir. Kurs süresinin yetersizliği ve uygun olmayan zamanda yapılmış olması, pratik eksikliği hem öğretmenler hemde formatör öğretmenler tarafindan vurgulanmıştır. Bu bulgular öğretmenlerin bulgulariyla karşılaştıııldığında alt yap1 sorunlanı, zaman, pratik eksikliği ve kısmende katıllımcı özellikleri konusunda öğretmenlerin ve formatör öğretmenlerin benzer görüşlere sahip oldukları görülmektedir. Bunun yanında formatör öğretmenler programın yetersizliğini vurgulamışlardır. Dolayısıyla öğretmenlerin pratik eksikliği, eğitmen niteliği gibi vurguladıkları bazı temaların aslında programın yetersizliğinden kaynaklandığı düşünülebilir.

$\mathrm{Bu}$ araştırmadan elde edilen sonuçlar değerlendirildiğinde öğretmenlerin ETKK etkinlik programının kazanımlarına genel olarak sahip olduklarını belirlenmiştir. Fakat bunun yanında bazı kazanımlar konusunda istenilen düzeyde olmadıkları görülmektedir. Nitel verilerden elde edilen öğretmenlerin kursun katkılarına ilişkin görüşlerinin de nicel bulgularla paralel olarak eğitimde teknoloji entegrasyonu, etkileşimli tahta kullanımı, materyal hazırlama ve kullanmanın ön plana çıktığı belirlenmiştir. Öğretmenlerin ETKK etkinlik programındaki aksaklıklara ve sorunlara ilişkin görüsslerinde ise zaman sorunları, alt yapı eksikliği, pratik eksikliği konularının daha çok vurgulandığ1 bunların yanında öğretmen özellikleri ve eğitmen niteliği kısmen vurgulanmıştır. Öğretmenlerin ve formatör öğretmenlerin görüşleri birlikte değerlendirildiğinde programın katkılarında eğitimde teknoloji kullanımını ön plana çıkardıkları sorunlar ve aksaklıklara ilişkin ise alt yapı eksikliği, katılımcı özellikleri, zaman, programın yetersizliği noktalarında elde edilen verilerin birbirini desteklediği görülmektedir. Ayrıca nicel kısımda yer alan bazı kazanımların istenen düzeyde olmaması yine nitel kısımda sorunlara ve aksaklıklara ilişkin elde edilen alt yapı eksikliği, programın yetersizliği, katılımcı özellikleri, zaman, pratik eksikliği temalarıyla ilişkili olduğu söylenebilir. Bu bağlamda nicel ve nitel verilerin hem kendi içinde hem de kendi arasında birbirini destekleyerek üçgenleme yapmaya olanak sağladığ1 söylenebilir.

$\mathrm{Bu}$ çalışmadan elde edilen sonuçlar ETKK hizmetiçi eğitim programının kısmen başarılı olduğu ancak aksaklıkların ve sorunlarında olduğunu göstermektedir. Kurt ve arkadaşlarının (2013)'ün çalışmalarında da öğretmenler FATİH Projesiyle birlikte teknoloji yeterliklerinin arttığını dile getirmişlerdi. $\mathrm{Bu}$ bulgu mevcut çalısmadaki teknoloji kullanımı yeterliklerinin de ön plana çıkması bulgusuyla paralellik göstermektedir. Yıldız, Sarıtepeci ve Seferoğlu (2013)'ün FATİH projesi kapsamında düzenlenen hizmet-içi eğitim etkinlikleri ISTE standartlarına göre değerlendirdikleri çalışmalarında hizmet-içi eğitimlerin öğretmenlerin mesleki gelişimlerine katk1 sağlamadığ1 belirlenmiştir. Bunun yanında öğretmenler hizmetiçi programların içeriğinin yoğunluğunu ve zamanın yetersizliğini vurgulamışlardır. Ayrıca öğretmenler en çok karşılaştıkları sorunların teknik sorunlar ve alt yapı eksikliği olduğunu ifade etmişlerdir. Mesleki gelişim programlarının zamanının uygun olmaması veya yetersiz olmasının önemli bir mesleki gelişim engeli olduğu birçok çalışma da (OECD, 2009; 2014; Ekşi, 2010; David ve Bwisa, 2013) belirtilmiştir. Banoğlu, Madenoğlu, Uysal ve Dede (2014)'nin çalışmalarında FATïH projesindeki hizmetiçi eğitimlerin daha çok teorik ve kısa süreli olduğu ve katılımcıların isteksiz olduğu vurgulanmıştır. Bu bulgular bu araştırmada elde edilen bulguları destekler niteliktedir. Bu çalş̧mada e- içerik geliştirilmesi konusundaki eksiklikleri öğretmenler EBA' dan yeterince yararlanmadıklarını, branşlarına uygun yeterli içeriğin ve uygulamaların olmadığını belirtmişlerdir. Bu bulguyla paralel olarak Yıldız ve diğ (2013), Gürol, Donmuş ve Aslan (2012) ve Ekici ve Yılmaz (2013)'ün çalışmalarında da bu eksikliğe vurgu yapıldığı görülmektedir. Benzer şekilde Özkan ve Deniz (2014)'in çalışmalarında da FATİH projesindeki teknolojilerin derslerde kullanılabilmesi için gerekli e-içeriğin olmadığ1, öğretmenlere sunulan hizmetiçi eğitim sürecinde öğretmenlerin BT'yi kullanma deneyimine yeterince sahip olmadıklarını tespit etmişlerdir. Bu bulgular bu çalışmadaki alt yapı eksikliği ve öğretmen özelliği temalarındaki bulgularla paraleldir. Bu çalışmanın bulgularından olan eğitmenlerin niteliklerine ilişkin sorunlarda hizmetiçi eğitimlerin niteliğini etkilemektedir. Ültanır ve Akay (2010)'in da belirttiği gibi, öğretmenlere yönelik mesleki gelişim etkinliklerinde görev alan eğitmenler, yetişkin eğitimi alanında da eğitim almış olmalıdır. Akıncı, Kurtoğlu ve Seferoğlu (2012) FATİH projesinin başarılı olabilmesi için yapılması gerekenlere ilişkin yaptıkları durum analizi 
İzci, E. \& Eroğlu, M. (2016). Eğitimde Teknoloji Kullanımı Kursu hizmetiçi eğitim programının değerlendirilmesi. International Journal of Human Sciences, 13(1), 1666-1688. doi:10.14687/ijhs.v13i1.3584

çalışmasında projenin uygulanabilir olmasında başrol oynayacak en önemli öğelerden birinin öğretmenler olduğu belirtmişlerdir. Proje uygulamalarının sürdürülebilir olması için ana uygulayıcılar olarak görülen öğretmenlere yönelik sürekli mesleki eğitimlerin sağlanması ve onların sürece etkin olarak katılımlarının sağlaması önem arz ettĭği ifade etmişlerdir. Bu bağlamda hizmetiçi eğitimlerin hem sayıca hem de nitelik olarak artırılması önemlidir. Çünkü hizmetiçi eğitimler öğretmenlerin mesleki gelişimi için önemlidir. Bir mesleki gelişim programı olarak değerlendirilen hizmetiçi eğitimlerin niteliği arttırılmalıdır. Garet, ve arkadaşları (2001) etkili bir mesleki gelişim programının, alan bilgisi odaklı, uzun süreli, katılımcılara aktif öğrenme firsatı veren, işbirlikçi katılım sağlayan, programla, standartlarla ve öğretmenin geçmiş bilgileriyle ve yaşantılarıla uyumlu olması gibi bazı özellikleri taşıması gerektiugini ifade etmişlerdir. Bu çalışmadan elde edilen sonuçlar etkili mesleki gelişim programının özellikleri doğrultusunda değerlendirildiğinde bu özellikleri karşılayamadığ1 görülmektedir. Bu hizmetiçi eğitim programında farklı branşta öğretmenlerin bir arada olduğu ve programin genel olduğu, sürenin yetersiz olduğu, öğretmenlere yeterince aktif öğrenme ve pratik yapma firsatı verilmediği, katılımcılar arası işbirliğinin yetersiz olduğu bu araştırmanın sonuçlarından da görülebilmektedir.

Hizmetiçi eğitim programlarının değerlendirilmesi ve bu değerlendirme sonuçlarından hareketle geliştirilmesi hem FATİH projesinin amacına ulaşması hem de eğitimde niteliğin artırılmasına katkı sağlaması beklenmektedir. Bu çalısmanın da FATİH projesi kapsamında yürütülen ETKK etkinlik programının değerlendirilmesi bağlamında önemli katkılarının olabileceği düşünülmektedir. Araştırmadan elde edilen bu sonuçlar doğrultusunda teknoloji alanı ile ilgili olarak hizmetiçi eğitim programlanına ilişkin şu önerilerde bulunulabilir:

- Hizmetiçi eğitim programlanında uygulamaya ağırlık verilmelidir. Öğretmenlere daha fazla pratik yapma ve aktif öğrenme imkanı sağlanabilir.

- Hizmetiçi eğitim programlarının süresi belirlenirken katılımcıların farklı özellikleri göz önünde bulundurularak kurs saati yeterli olacak şekilde belirlenmesine dikkat edilmelidir.

- Hizmetiçi eğitim programlarının zamanı belirlenirken zamanın öğretmenler için uygun olmasına dikkat edilebilir (ders saatiyle çakışmaması, yorgun ve meşgul olabilecekleri saatlerin dişında olması).

- Hizmetiçi eğitim programları öğretmenlerin ilgisini çekecek, motivasyonlarını artıracak şekilde düzenlenebilir.

- Hizmetiçi eğitim programları branş bazında düzenlenebilir.

- EBA'nın her branşa yönelik uygulamalarla zenginleştirilmesi sağlanabilir.

- Hizmetiçi eğitim programları uygulanmadan önce alt yapı eksiklikleri (ekipman eksikliği, doküman eksikliği, ortam) giderilebilir.

- Hizmetiçi eğitim programını uygulayacak eğitmenlerin niteliğinin arttırılabilir.

- Hizmetiçi eğitimlerin daha sık ve küçük gruplarla yapılabilir.

- Hizmetiçi eğitim programlarının değerlendirilmesi ve geliştirilmesine ilişkin daha kapsamlı akademik çalışmalar yapılabilir.

\section{Kaynakça}

Adıgüzel, A. (2010). İlköğretim okullarında öğretim teknolojilerinin durumu ve sınıf öğretmenlerinin bu teknolojileri kullanma düzeyleri. Dicle Üniversitesi Ziya Gökalp Eüitim Fakïltesi Dergisi, 15, 1-17.

Akınc1, A., Kurtoğlu, M. ve Seferoğlu, S.S. (2012). Bir teknoloji politikası olarak FATİH Projesinin başarılı olması için yapılması gerekenler: Bir durum analizi çalışması. Akademik Bilişim (1-3 Şubat), Ușak Üniversitesi, Uşak. 
İzci, E. \& Eroğlu, M. (2016). Eğitimde Teknoloji Kullanımı Kursu hizmetiçi eğitim programının değerlendirilmesi. International Journal of Human Sciences, 13(1), 1666-1688. doi:10.14687/ijhs.v13i1.3584

Banoğlu, K., Madenoğlu, C., Uysal, Ş. Ve Dede, A. (2014). FATİH projesine yönelik öğretmen görüşlerinin incelenmesi (Eskişehir ili örneği). Eğitim Bilimleri Araștormalar Dergisi (EBAD), 4(1), 39-58.

Bümen, N. T., Ateş, A., Çakar, E., Ural, G., ve Acar, V. (2012). Türkiye bağlamında öğretmenlerin mesleki gelişimi: sorunlar ve öneriler. National Education,194, 31-49.

Creswell J. W., \& Clark, V. L. P. (2014) Karma yöntem desen seçimi(Çev. A. Delice). Karma yöntem arasstırmalar tasarmı ve yürütülmesi (Çev. Ed. Y. Dede, S. B. Demir) Anı Yayıncilik.

Çakır, R., ve Oktay, S. (2013). Bilgi toplumu olma yolunda öğretmenlerin teknoloji kullanımları. Gaæi Üniversitesi Endüstriyel Sanatlar Ë̈itim Fakültesi Dergisi, Say1: 30, 35-54.

David, M. N., ve Bwisa, H. M. (2013). Factors Influencing Teachers' Active Involvement in Continuous Professional Development: A Survey in Trans Nzoia West District, Kenya. International Journal of Academic Research in Business \& Social Sciences, 3(5).

Demirer, V., Saban, A., Küçük, Ş. ve Şahin, İ. (2011). Bilişim teknolojileri öğretmen adaylarının FATİH projesi hakkındaki görüşlerinin değerlendirilmesi. 11. Internatıonal Educatıonal Technology Conference (25-27 May), İstanbul, Turkey.

Ekici, S., \& Yllmaz, B. (2013). FATİH projesi üzerine bir değerlendirme. Türk Kütü̈haneciliği, 27(2), 317-339.

Ekşi, G. (2010). An Assessment of the Professional Development Needs of English Language Instructors Working at a State Unwersity. Unpublished Master Thesis. Middle East Technical University Department of Educational Sciences, Ankara.

Eğitim Reformu Girişimi(ERG), (2013). FATİH projesi eğitimde dönüşüm için bir firsat olabilir mi? politika analizi ve önerileri. http://www.tbv.org.tr/theme/images/ckeditor/files/ERG Fatih Projesi.pdf adresinden $\underline{04.02 .2016}$ tarihinde ulaşılmıştır.

Ertmer, P. A. (2005). "Teacher pedagogical beliefs: The final frontier in our quest for technology integration?" Educational Technology Researchand Development, 53(4), 25-39

Eryllmaz, S., \& Salman, Ş. (2014). Fatih projesi kapsaminda yer alan öğretmen ve öğrencilerin projeden beklentileri ve bilişim teknolojileri kullanımına karşı algıları. Elektronike Mesleki Gelisim ve Arastirmalar Dergisi, 2(1), 46-63.

Garet, M. S., Porter, A. C., Desimone, L., Birman, B. F., \& Yoon, K. S. (2001). What makes professional development effective? Results from a national sample of teachers. American educational research journal, 38(4), 915-945.

Gürol, M., Donmus, V. \& Arslan, M. (2012). İlköğretim kademesinde görev yapan sınıf öğretmenlerinin fatih projesi ile ilgili görüşleri. Eğitim Teknolojileri Arasstırmalar Dergisi, 3(3).

Have, P. T. (2004). Understanding Qualitative Research and Ethnomethodology. London: SAGE Publications.

Kayaduman, H., Sırakaya, M., \& Seferoğlu, S. S. (2011). Eğitimde FATİH projesinin öğretmenlerin yeterlik durumları açısından incelenmesi. Akademik bilisim, 2-4.

Kurt, A. A., Abdullah, K. U. Z. U., Dursun, Ö. Ö., Güllepınar, F. ve Gültekin, M. (2013). FATİH projesinin pilot uygulama sürecinin değerlendirilmesi: Öğretmen görüşleri. Journal of Instructional Technologies \& Teacher Education, 2(1).

Leech, N. L., ve Onwuegbuzie, A. J. (2009). A typology of mixed methods research designs. Quality \& Quantity, 43(2), 265-275.

MEB (2012). Fatih öğretmen eğitimi. http:// fatihprojesi.meb.gov.tr/tr/icerikincele.php?sayfa $=2 \& i d=5$ adresinden 03.02.2016 tarihinde ulaşılmıştır.

MEB (2013a). Fatih Projesi- Eğitim Teknolojileri Genel Müdürlüğü http://fatihprojesi.meb.gov.tr/tr/icerikincele.php?id=6 adresinden 28.12.2013 tarihinde ulaşılmıştır. 
İzci, E. \& Eroğlu, M. (2016). Eğitimde Teknoloji Kullanımı Kursu hizmetiçi eğitim programının değerlendirilmesi. International Journal of Human Sciences, 13(1), 1666-1688. doi:10.14687/ijhs.v13i1.3584

MEB, (2013b). Hizmetiçi eğitim program1. http://hedb.meb.gov.tr/net/ Duyuru dosyalar/fatih/EK-2.pdf adresinden 28.12.2013 tarihinde ulaşılmıştır.

Miles, M.B. ve Huberman, A.M. (2015). Nitel veri analiz̨i (İkinci baskıdan çev.) (S. Akbaba ve A. E. Altun Çev Ed.). Pegem Akademi, Ankara.

OECD (2009). Creating Effective Teaching and Learning Environments First Results from TALIS. OECD Publishing. http://www.oecd.org/education/school/43023606.pdf adresinden 13.06.2014 tarihinde indirilmiştir.

OECD (2014). TALIS 2013 Results An International Perspective on Teaching and Learning. OECD Publishing. http://www.oecd-ilibrary.org/education/talis-2013-results 9789264196261-en adresinden 12.06.2014 tarihinde ulaşılmıştır.

Özdemir, M. (2010). Nitel veri analizi: Sosyal bilimlerde yöntembilim sorunsalı üzerine bir çalışma. Eskişehir Osmangazi Üniversitesi Sosyal Bilimler Dergisi,11(1).

Özkan, A., ve Deniz, D. (2014). Orta öğretimde görev yapan öğretmenlerin FATİH projesi'ne ilişkin görüşleri. Ege Eğitim Dergisi, 15(1), 161-175.

Tatlı, C., ve Kılıç, E. (2013). Etkileşimli tahtaların kullanımına ilişkin alınan hizmetiçi eğitimin öğretmen görüşleri doğrultusunda değerlendirilmesi. Journal of Educational Sciences \& Practices, 12(24), 137-158.

TOBB Bilgi Hizmetleri Dairesi (2010). Sınıflar evrensel hizmet fonu ile akıllanacak. Bilişim Teknolojileri Haber Bülteni. Türkiye Odalar ve Borsalar Birliği Bilgi Hizmetleri Dairesi Bülteni, (60), 9. http://www.tobb.org.tr/BilgiHizmetleri/Documents/Bulten/2010 12.pdf adresinden 04.02.2016 tarihinde ulaşılmıştır.

Usta, E., ve Korkmaz, Ö. (2010). Öğretmen adaylarının bilgisayar yeterlikleri ve teknoloji kullanımına ilişkin algıları ile ögretmenlik mesleğine yönelik tutumları. Uluslararası İnsan Bilimleri Dergisi, 7(1), 1335-1349.

Ültanır, Y. G., ve Cenk, A. (2010). MEB hızmetıçı egıtıcılerının egıtım uygulamalarının olusturmacılık ve dogrudan ögretım modelıne göre yorumlanması. NWSA: Education Sciences, 5(2), 584-595.

Yeşilyurt, E. (2007). Öğretim araç-gereçleri kullanımına etki eden faktörler. e-Journal of New World Sciences Academy, 2(4), 300-312.

Yıldız, H., Sarıtepeci, M., \& Seferoğlu, S. S. (2013). FATïH projesi kapsamında düzenlenen hizmetiçi eğitim etkinliklerinin öğretmenlerin mesleki gelişimine katkılarının ISTE öğretmen standartlar1 açısından incelenmesi. Hacettepe Üniversitesi Eŭitim Fakültesi Dergisi [Hacettepe University Journal of Education], Özel sayn, 1, 375-392.

\section{$\underline{\text { Extended English Abstract }}$}

Education systems need to prepare new curriculum, materials in line with technological developments. Turkish education system is affected by these developments, too. In this context, Movement of Enhancing Opportunities and Improving Technology", known as FATIH, is among the most significant educational investments of Turkey. Turkey has initiated FATIH Project with the aim enabling equal opportunities in education and improving technology in schools for the efficient usage of ICT tools in the learning-teaching processes by appealing to more sensory organs in all 42.000 schools and 570.000 classes that are in the preschool education, the primary education and the secondary education through providing tablets and LCD Interactive Boards. In-service Trainings for teachers are going to be held in order to provide effective usage of the ICT equipment in the classrooms in the learning- teaching process. These training programs are seminar of introduction to FATIH project (8 hours), conscious, safe usage of ICT and internet seminar (10 hours), FATIH project preparatory training seminar (25 hours) and the course of technology 
İzci, E. \& Eroğlu, M. (2016). Eğitimde Teknoloji Kullanımı Kursu hizmetiçi eğitim programının değerlendirilmesi. International Journal of Human Sciences, 13(1), 1666-1688. doi:10.14687/ijhs.v13i1.3584

usage in education ( 25 hours). These in-service training programs organized by National Education Ministery localy and training programs lectured by formator teachers who are expertise on ICT. Inservice training is very important for both succes of FATIH project and teachers' professional development. So in-service training programs should be evaluated to improve quality of in-service training program. The course of technology usage in education is the backbone of in-service training programs within the scope of FATIH Project. Because the course of technology usage in education focus on main purposes of FATIH project like installation of ICT equipment, use of interactive whiteboards, material design, material selection, material evaluation etc. The aim of present study evaluate the course of technology usage in education in-service training program within the scope of FATIHH project according to opinions' of teachers and formator teachers.

The study is mixed method research and carried out by applying the convergent parallel design. Since program evaluation studies require the use of different data sources and data collection tools to evaluate program holistically, this method was used in this study. For the quantitative strand of the research, data were collected through survey consisting of objectives related to in-service training program from totally 92 teachers. The qualitative data were collected through interview consisting of open ended questions related to contrubition and problems of inservice training program from 49 teachers and 5 formator teachers who volunteered to participate in the study. Descriptive statistics were used to analyze the quantitative data obtained from research and the content analysis was used to analyze qualitative data.

According to research findings, in-service training program was partially successful but there are some deficits and problems related to in service training program. Teachers reported that in-service training program contribute to teachers in the context of integration of technology in education but there are problems related to in-service training program as a points of time, infrastructure and practice. Teacher highlighted in service training course time is in sufficient and conflict with work schedule much. Also they higlighted infrastructure problems related to in service education and FATIHH Project. Another problem related to in service training is lack of practice. Teachers reported they couldn't enough practice related to using educational technology in inservice education. Formator teachers reported that in-service training program contribute to teachers in the point of using educational technologies but they reported that there are problems in the points of participant characteristics, quality of program, infrastructure and time. Formator teachers highlighted participant teachers unwillingnes, worried and in insufficiency about using technology. Also formator teacher reported in-service training program is not qualified enough because of insufficient time, lack of practice and density of course content. Formator teachers highlighted infrastructure problems like other participant teachers.

The result of study shows that quality of this in-service training program is not at desired level and this result has been supported by quantitative and qualitative findings in this study. Findings obtained by this study is consistent with findings of other studies in literature as a points of time problems (insufficient time, conflict with work schedule), infrastructure problems (lack of digital document and technical support), unqualified in-service program, lack of practice, participants features (unwillingness, insufficient competency and worry). According to these results some practical recommendations in regard in-service training program can be provided. The duration of the activity, opportunities for active learning, focus on content knowledge are very important for quality of professional development programs. When in-service training programs prepare, some features like duration of the activity, participant features, active learning opportunities, should be taken into consideration. Also in the process of in-service training programs very important for the success of in-service training programs. So infrastructure and quality of lecture should be taken into consideration, too. 